\title{
Phytochemical Analysis and In Vitro Effects of Allium fistulosum L. and Allium sativum L. Extracts on Human Normal and Tumor Cell Lines: A Comparative Study
}

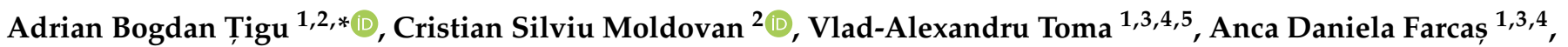 \\ Augustin Cătălin Moț ${ }^{6}$, Ancuța Jurj ${ }^{7}$, Eva Fischer-Fodor ${ }^{2,8}\left(\mathbb{D}\right.$, Cristina Mircea ${ }^{1}$ and Marcel Pârvu ${ }^{1, * \mathbb{C}}$
}

1 Faculty of Biology and Geology, Babeș-Bolyai University, 42 Republicii Street, 400015 Cluj-Napoca, Romania; vlad.al.toma@gmail.com (V.-A.T.); farcasanca14@gmail.com (A.D.F.); cristina.mircea@ubbcluj.ro (C.M.)

2 Research Center for Advanced Medicine-MedFuture, "Iuliu Hatieganu" University of Medicine and Pharmacy Cluj-Napoca, Louis Pasteur Street 6, 400349 Cluj-Napoca, Romania; moldovan.cristian1994@gmail.com (C.S.M.); fischer.eva@iocn.ro (E.F.-F.)

3 National Institute for Research and Development of Isotopic and Molecular Technologies, 400293 Cluj-Napoca, Romania

4 Institute of Biological Research, Branch of NIRDBS Bucharest, 400113 Cluj-Napoca, Romania

5 Centre for Systems Biology, Biodiversity and Bioresurces "3B", Babeș-Bolyai University, 400000 Cluj-Napoca, Romania

6 Department of Chemistry, Faculty of Chemistry and Chemical Engineering, Babes-Bolyai University, 11 Arany Janos Street, 400028 Cluj-Napoca, Romania; gusty_chem@yahoo.com

Citation: T,igu, A.B.; Moldovan, C.S.; Toma, V.-A.; Farcaș, A.D.; Moț, A.C.; Jurj, A.; Fischer-Fodor, E.; Mircea, C.; Pârvu, M. Phytochemical Analysis and In Vitro Effects of Allium fistulosum L. and Allium sativum L. Extracts on Human Normal and Tumor Cell Lines: A Comparative Study. Molecules 2021, 26, 574. https: / / doi.org/10.3390/ molecules26030574

Academic Editors: Ana Lourenço and Jorge Gominho

Received: 28 December 2020

Accepted: 20 January 2021

Published: 22 January 2021

Publisher's Note: MDPI stays neutral with regard to jurisdictional claims in published maps and institutional affiliations.

Copyright: (C) 2021 by the authors Licensee MDPI, Basel, Switzerland. This article is an open access article distributed under the terms and conditions of the Creative Commons Attribution (CC BY) license (https:// creativecommons.org/licenses/by/ $4.0 /)$.
7 The Research Center for Functional Genomics, Biomedicine and Translational Medicine, "Iuliu Hatieganu" University of Medicine and Pharmacy, 400012 Cluj-Napoca, Romania; ancajurj15@gmail.com

8 Department of Radiobiology and Tumor Biology, The Oncology Institute "Prof Dr Ion Chiricuta", 400015 Cluj-Napoca, Romania

* Correspondence: adrianbogdantigu@gmail.com (A.B.T.); marcel.parvu@ubbcluj.ro (M.P.); Tel.: +40-727266516 (A.B.T.)

\begin{abstract}
Allium satioum L. (garlic bulbs) and Allium fistulosum L. (Welsh onion leaves) showed quantitative differences of identified compounds: allicin and alliin $(380 \mu \mathrm{g} / \mathrm{mL}$ and $1410 \mu \mathrm{g} / \mathrm{mL}$ in garlic; $20 \mu \mathrm{g} / \mathrm{mL}$ and $145 \mu \mathrm{g} / \mathrm{mL}$ in Welsh onion), and the phenolic compounds (chlorogenic acid, $p$-coumaric acid, ferulic acid, gentisic acid, 4-hydroxybenzoic acid, kaempferol, isoquercitrin, quercitrin, quercetin, and rutin). The chemical composition determined the inhibitory activity of Allium extracts in a dose-dependent manner, on human normal cells (BJ-IC 50 0.8841\% garlic/0.2433\% Welsh onion and HaCaT-IC 50 1.086\% garlic/0.6197\% Welsh onion) and tumor cells (DLD-1-IC 50 5.482\%/2.124\%; MDA-MB-231-IC 50 6.375\%/2.464\%; MCF-7-IC 50 6.131\%/3.353\%; and SK-MES-1$\left.\mathrm{IC}_{50} 4.651 \% / 5.819 \%\right)$. At high concentrations, the cytotoxic activity of each extract, on normal cells, was confirmed by: the $50 \%$ of the growth inhibition concentration $\left(\mathrm{IC}_{50}\right)$ value, the cell death induced by necrosis, and biochemical determination of $\mathrm{LDH}$, catalase, and Caspase- 3 . The four tumor cell lines treated with high concentrations $(10 \%, 5 \%, 2.5 \%$, and $1.25 \%)$ of garlic extract showed different sensibility, appreciated on the base of $\mathrm{IC}_{50}$ value for the most sensitive cell line (SK-MES- 1 ), and the less sensitive (MDA-MB-231) cell line. The high concentrations of Welsh onion extract (5\%, 2.5\%, and $1.25 \%$ ) induced $\mathrm{pH}$ changes in the culture medium and SK-MES-1 being the less sensitive cell line.
\end{abstract}

Keywords: Allium; necrosis; apoptosis; toxicity; allicin; antiproliferative

\section{Introduction}

Allium plants have been used in traditional medicine since ancient times. Currently, studies regarding the phytotherapeutical properties of Allium species are investigating the effects of Allium extracts and bioactive compounds [1,2]. Allium species are still studied 
due to their bioactive compounds [1]. Most of the studies regarding the phytotherapeutical properties of Allium species are focused on Allium satioum (garlic) and Allium cepa (onion). Allium plants are rich in bioactive compounds like alliin, allicin, ajoene, sterols, flavonoids, polyphenols, and polycarboxylic acids, which are responsible for the biological effects of different Allium species [3].

Garlic is one of the most cultivated therapeutical plants [4]. The studies focused on the curative capacities of garlic highlighted its antioxidative properties [5], hypoglycemic and cardioprotective effects [6,7], anticancer [8], antifibrotic [9], and antifungal properties [10].

The antitumoral effect of garlic induced by its bioactive sulfur compounds like allicin, diallyl-sulfides (DAS), diallyl-disulfides (DADS), and diallyl-trisulfides (DATS), raises interest for many studies [11-13]. DATS can stimulate cytotoxicity by targeting reactive oxygen species (ROS) and can activate the ROS dependent caspase pathway, therefore it can promote apoptosis [14]. Sulfur compounds act as upregulators for antioxidant genes, can promote Nrf2-ARE activation, and are potent inhibitors of the inflammatory process $[15,16]$. Not only the sulfur compounds but also the flavonoids and saponins present in Allium species were investigated for their cytotoxic, antiproliferative, proapoptotic, antiangiogenic, or antimetastatic potential on numerous human cancers line [2,17]. Usually, the anticancer mechanisms activate the apoptosis-related genes caspases (caspase-3, -8, and -9) and bcl2 [18].

Isolated bioactive compounds present in garlic, and obtained extracts, were investigated for their anticancer potential. Allicin is the result of hydrolyzed alliin under alliinase enzyme action, with ajoene as a secondary compound resulted after alliin decomposition [15,19]. Allicin has an immunostimulatory effect [19] and antitumoral properties by inhibiting cell proliferation, migration, and enhancing apoptosis [12,20-22]. The antitumor effect of allicin was investigated on different tumor cell lines like cervical cancer, breast cancer, colorectal cancer, gastric cancer, glioblastoma, leukemia, lymphoma, and endometrial adenocarcinoma [23-33].

Various Allium extracts, aqueous or alcoholic, were tested individually as a single agent treatment or combined with cancer therapeutically drugs in several cancer lines like oral and lung [34], breast, cervical, colon and liver [35-39], leukemia [40], and squamous carcinoma [41]. Allium sativum extracts were also proven to have cytotoxic effects on multidrug-resistant human cancer cells by altering the mitochondrial permeability [42].

Welsh onion (Allium fistulosum L.) is less studied compared to garlic. It is a common Allium plant in Eastern Europe, with antifungal and antimicrobial properties, due to its high concentration of sterols and sulfuric compounds [43]. The studies investigating $A$. fistulosum biological properties highlighted mostly the anti-inflammatory and antioxidant effects, while the antitumor potential was elevated on the MDA-MB-453 metastatic breast cancer cell line, in which the Welsh onion stimulated early apoptosis [44].

Natural compounds represent potential candidates in fighting against various diseases. A pure compound, isolated and well characterized, can serve as a therapeutic agent alone or in combination with conventional therapy, due to its biological properties [45-51].

The aim of this study is to investigate the in vitro effect of two Allium species that present high interest as being therapeutical agents. The presented characterization and investigation of $A$. sativum and $A$. fistulosum can provide scientific information that may lead to further studies.

\section{Results and Discussions}

\subsection{Phytochemical Characterization}

Both Allium extracts were analyzed to investigate the concentration of alliin and allicin. Four samples of each extract were prepared according to the protocol and the concentration of compounds was expressed in $\mu \mathrm{g} / \mathrm{mL}$ (Table 1 ).

Garlic extract contained $1410 \mu \mathrm{g} / \mathrm{mL}$ of alliin and $380 \mu \mathrm{g} / \mathrm{mL}$ of allicin, a lot more than $A$. fistulosum extract that contained only $145 \mu \mathrm{g} / \mathrm{mL}$ of alliin and $20 \mu \mathrm{g} / \mathrm{mL}$ of allicin (Table 1). 
Table 1. Elution time, analytical method characteristics, and determined concentrations of alliin, allicin, and phenolic acids and flavonoids in the Allium extract samples (results expressed as the mean value of 4 analyzed samples, $n=4$ ).

\begin{tabular}{|c|c|c|c|c|c|c|}
\hline No & Compounds & $t_{\text {elution }}(\min )$ & $\mathbf{R}^{2}$ & $\begin{array}{l}\text { LOD } \\
(\mu \mathrm{g} / \mathrm{mL})\end{array}$ & $\begin{array}{l}\text { A. sativum } \\
(\mu \mathrm{g} / \mathrm{mL})^{*}\end{array}$ & $\begin{array}{l}\text { A. fistulosum } \\
(\mu \mathrm{g} / \mathrm{mL})\end{array}$ \\
\hline 1 & Alliin & 3.77 & 0.9999 & 5.8 & $1410 \pm 50$ & $145 \pm 15$ \\
\hline 2 & Allicin & 15.40 & 0.9999 & 14.1 & $380 \pm 15$ & $20 \pm 5$ \\
\hline 3 & Gentisic ac. & 8.13 & 0.9997 & 3.4 & $60 \pm 5$ & - \\
\hline 4 & Chlorogenic ac. & 9.15 & 0.9995 & 4.6 & $65 \pm 5$ & - \\
\hline 5 & 4-hydroxybenzoic & 10.31 & 0.9999 & 2.3 & $25 \pm 3$ & - \\
\hline 6 & Rutin & 11.39 & 0.9998 & 2.7 & - & $215 \pm 3$ \\
\hline 7 & Isoquercitrin & 11.91 & 0.9999 & 2.2 & - & $280 \pm 3$ \\
\hline 8 & $p$-Coumaric & 12.38 & 0.9999 & 1.9 & $44 \pm 4$ & - \\
\hline 9 & Quercitrin & 12.72 & 0.9998 & 2.7 & - & $95 \pm 3$ \\
\hline 10 & Ferulic ac. & 12.85 & 0.9999 & 2.0 & - & $230 \pm 2$ \\
\hline 11 & Quercetin & 16.35 & 0.9997 & 3.3 & - & $26 \pm 3$ \\
\hline 12 & Kaempferol & 19.77 & 0.9998 & 2.7 & - & $30 \pm 3$ \\
\hline
\end{tabular}

LOD—limit of detection, $\mathrm{R}^{2}$-coefficient of determination for the calibration curves (at six levels of concentrations). Indicated intervals represent the average \pm standard deviations $(n=4) .{ }^{*}$ The information regarding Allium satioum was previously published by Pârvu et al. [10].

Same as for alliin and allicin determinations, four samples of both extracts were prepared and analyzed for phenolic acids and flavonoids content. As presented in Table 1, A. fistulosum is rich in isoquercitrin $(280 \mu \mathrm{g} \mu \mathrm{g} / \mathrm{mL})$, ferulic acid $(230 \mu \mathrm{g} / \mathrm{mL})$, and rutin $(215 \mu \mathrm{g} / \mathrm{mL})$, whereas A. sativum has $65 \mu \mathrm{g} / \mathrm{mL}$ of chlorogenic acid, $44 \mu \mathrm{g} / \mathrm{mL}$ of $p$ coumaric acid, and $25 \mu \mathrm{g} / \mathrm{mL}$ of 4-hydroxybenzoic acid.

\subsection{Evaluation of the Acute Effect on Human Normal Cell Viability}

To explore the Allium extracts toxicity on human normal fibroblasts (BJ) and human normal keratinocytes (HaCaT), the viability of these cells was assessed by an MTT assay at $24 \mathrm{~h}$. As presented in Figure 1, the A. sativum extract inhibited the growth of $\mathrm{BJ}$ and $\mathrm{HaCaT}$ cells in a dose dependent manner, with the $50 \%$ of the growth inhibition concentration $\left(\mathrm{IC}_{50}\right)$ value of $0.8841 \%$ in the growth medium for BJ cells, equivalent to $8.841 \mathrm{mg} / \mathrm{mL}$ and $1.086 \%$ in the growth medium for $\mathrm{HaCaT}$ cells at $1.086 \%$ equivalent to $10.86 \mathrm{mg} / \mathrm{mL}$. When calculating the equivalent of extract in $\mathrm{mg} / \mathrm{mL}$ we used the concentrations of stock solutions for each extract, $1 \mathrm{~g}$ garlic bulbs in each $\mathrm{mL}$ and $1 \mathrm{~g}$ of Welsh onion leaves in each $1.2 \mathrm{~mL}$.

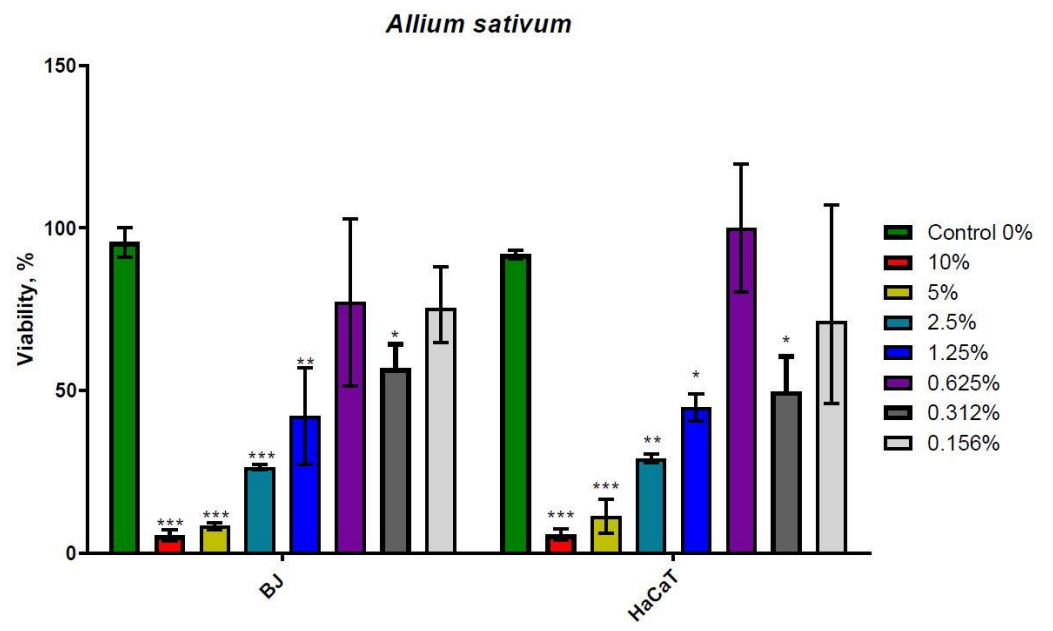

Figure 1. Twenty-four hour MTT Assay on BJ and HaCaT treated with Allium sativum. ${ }^{*} p<0.05$, ** $p<0.01$, and ${ }^{* * *} p<0.001$ when comparisons were made with the $C$ group. Garlic hydroalcoholic extract induces cell death in a dose dependent manner in both cell lines. The control group is represented by the untreated cells, which were cultivated with standard cell culture medium. 
A. fistulosum extract also presents inhibitory activity on both cell lines included in this study (Figure 2). $\mathrm{IC}_{50}$ value for $\mathrm{BJ}$ was $0.2433 \%$ in the growth medium; equivalent to $2.019 \mathrm{mg} / \mathrm{mL}$, while for HaCaT cells $\mathrm{IC}_{50}$ value was $0.6197 \%$ equivalent to $5.144 \mathrm{mg} / \mathrm{mL}$.

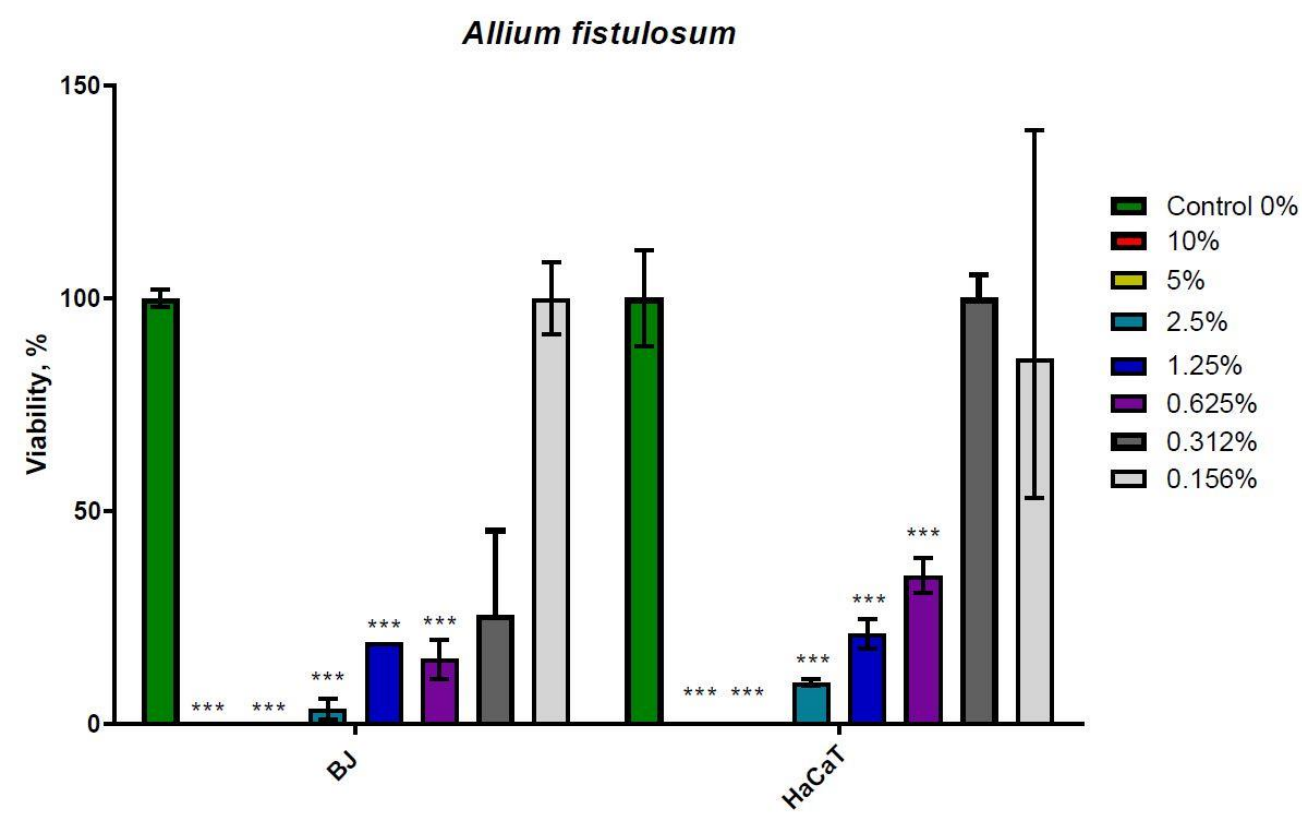

Figure 2. Twenty-four hour MTT Assay on BJ and HaCaT treated with Allium fistulosum. ${ }^{* * *} p<0.001$ when comparisons were made with the $C$ group. Welsh onion hydroalcoholic extract induces cell death in a dose dependent manner in both cell lines. The control group is represented by untreated cell, which were cultivated with standard cell culture medium.

Both A. sativum and A. fistulosum extracts have dose-dependent antiproliferative potential. At concentrations higher than $1.25 \%$ extract in the cell culture medium, garlic extract had lower inhibitory potential on $\mathrm{BJ}$ and $\mathrm{HaCaT}$ proliferation. On the other hand, Welsh onion extract fully inhibited cell growth at 5\% and $10 \%$ of extract in the cell culture medium, while below $1.25 \%$ of extract, the growth inhibitor was lowered in a dose dependent manner. The difference between extracts was visible at their $\mathrm{IC}_{50}$ values.

Normal human fibroblasts (BJ cells) and keratinocytes (HaCaT) were sensitive to garlic and Welsh onion extract with different half inhibitory doses $\left(\mathrm{IC}_{50}\right)$. Viability tests that were used in our study highlight the dose-dependent viability rate, with a very increased cell death for $100 \mathrm{mg} / \mathrm{mL}$ garlic extract and $86 \mathrm{mg} / \mathrm{mL}$ Welsh onion extract, which represent the $10 \%$ dose added to cells.

Growth inhibition was observed on the confocal microscopy analysis (Figures 3 and 4), morphological changes highlighting induced cell death in a dose dependent manner.

\subsection{Morphological Evaluation}

When cells are exposed to cytotoxic agents they tend to adapt if this is possible. At high concentrations of toxic compounds apoptosis is induced. During cell death the cytoskeleton collapses and the nuclear envelope disassembles and the DNA breaks into pieces, moreover the cell surface is modified. The intracellular mechanism of apoptosis is similar to almost all cells, caspases cleave key proteins in the cell, and some caspases cleave nuclear lamina or proteins that in normal situations keep DNAse in an inactive form, saving the DNA [52].

The most cytotoxic concentration seems to be the $10 \%$ garlic extract where the cytoskeleton and nucleus are almost gone, and the mitochondrial network is no more highlighted ( $\mathrm{D}$ for $\mathrm{BJ}$ and $\mathrm{H}$ for $\mathrm{HaCaT}$ ). The $\mathrm{IC}_{50}$ concentration for both cell lines had no cytotoxic effect; the nucleus and cytoskeleton are very well highlighted, and the mitochondrial network seems to be very active ( $C$ for $B J$ and $G$ for HaCaT). Cell structure and the 
morphological characteristics for cells that were treated with a lower extract dose than $\mathrm{IC}_{50}$ ( $\mathrm{B}$ for $\mathrm{BJ}$ and $\mathrm{F}$ for $\mathrm{HaCaT}$ ) were comparable with the control group (A for $\mathrm{BJ}$ and $\mathrm{E}$ for $\mathrm{HaCaT}$ ). These images confirmed the cytotoxic effect for both extracts at high concentration (10\% extract) and less cytotoxic at $\mathrm{IC}_{50}$ concentrations $(0.8841 \%$ for $\mathrm{BJ}$ and $1.086 \%$ for $\mathrm{HaCaT})$ and below $\mathrm{IC}_{50}(0.5 \%$ for $\mathrm{BJ}$ and $0.1 \%$ for $\mathrm{HaCaT})$, morphological modification with the disrupted cytoskeleton and mitochondrial network was indicating that cell death was induced by necrosis at $10 \%$ of extract. Morphological changes were less intense at $\mathrm{IC}_{50}$ concentrations and below compared to $10 \%$ of extract.

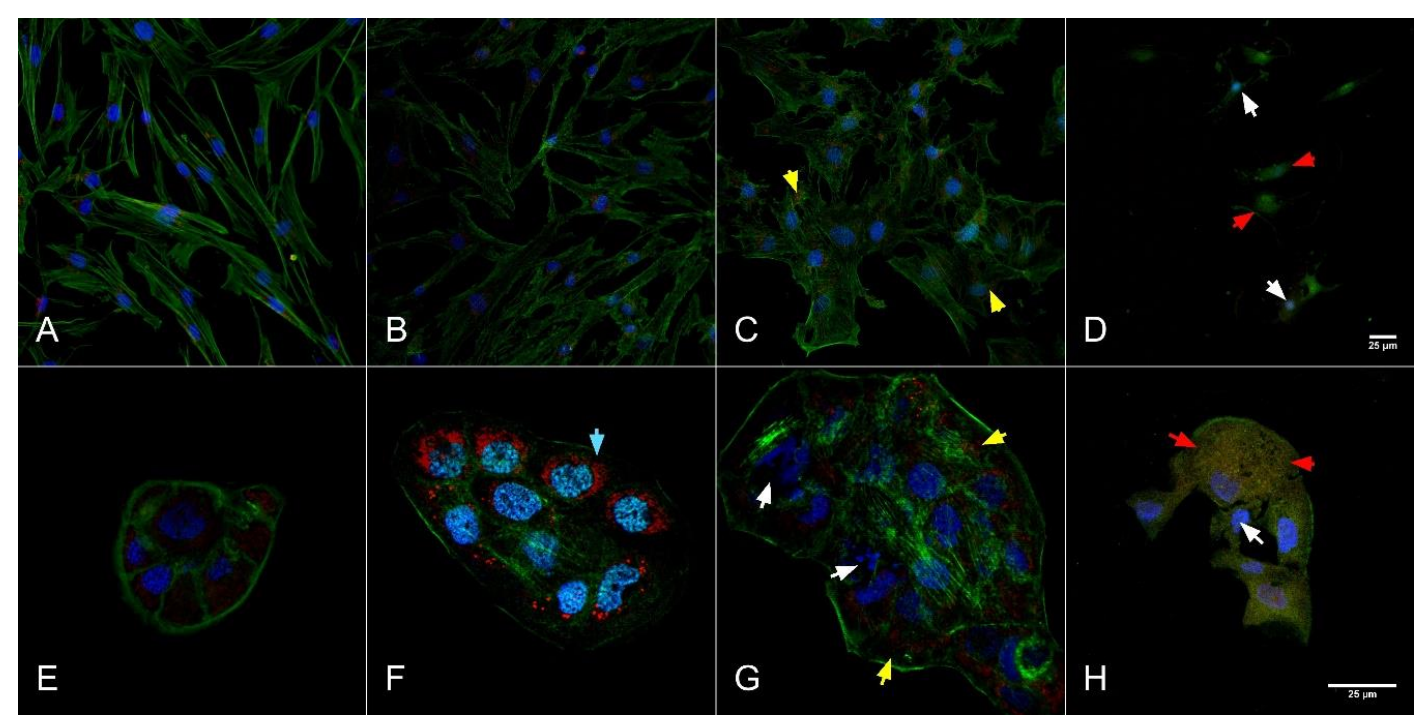

Figure 3. Allium sativum cytotoxic effect on BJ cells with a $40 \times$ objective ((A) - Control group, (B) - $0.5 \%$ extract, (C) - $50 \%$ of the growth inhibition concentration $\left(\mathrm{IC}_{50}\right)$ dose, and (D) - $10 \%$ extract) and HaCaT cells with $100 \times$ objective $((\mathbf{E})-\mathrm{Control}$ group, $(\mathbf{F})-0.1 \%$ extract, $(\mathbf{G})-\mathrm{IC}_{50}$ dose, and $(\mathbf{H})-10 \%$ extract). Cells were labeled with different strainers, DAPI for the nucleus (blue), Mitotracker for the mitochondria (red), and Phalloidin-FITC for the cytoskeleton (green). Nuclear damage-White arrows; Cytoskeleton disruption—Red arrows; Mitochondrial network reduced intensity-Yellow arrows; Mitochondrial intensified activity-Turquoise arrows.

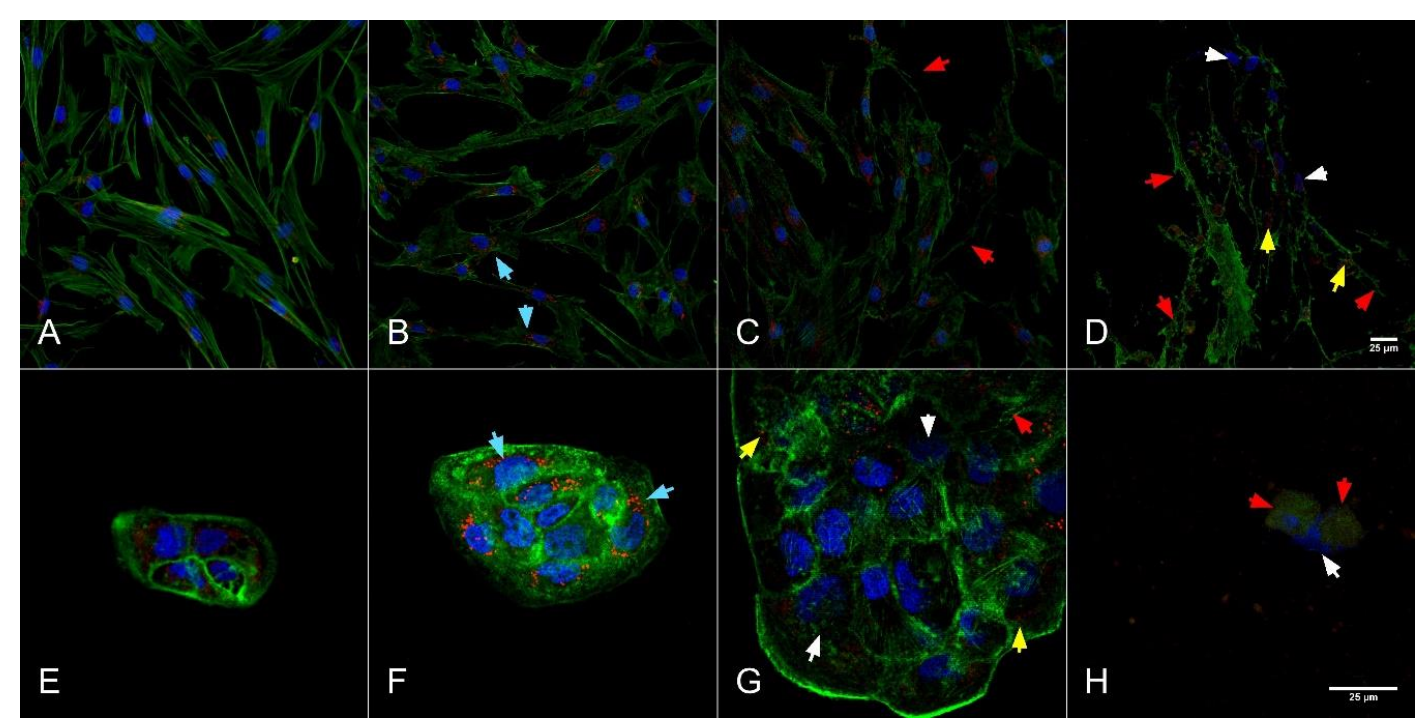

Figure 4. Allium fistulosum cytotoxic effect on BJ cells with $40 \times$ objective $\left((\mathbf{A})\right.$-Control group, $(\mathbf{B})-0.5 \%$ extract, $(\mathbf{C})-\mathrm{IC}_{50}$ dose, and (D) - 10\% extract) and HaCaT cells with $100 \times$ objective $\left((\mathbf{E})\right.$ - control group, $(\mathbf{F})-0.1 \%$ extract, $(\mathbf{G})$ - $\mathrm{IC}_{50}$ dose, and (H) $-10 \%$ extract). Cells were labeled with different strainers, DAPI for the nucleus (blue), Mitotracker for the mitochondria (red), and Phalloidin-FITC for cytoskeleton (green). Nuclear damage—White arrows; Cytoskeleton disruption-Red arrows; Mitochondrial network reduced intensity-Yellow arrows; Mitochondrial intensified activity—Turquoise arrows. 
The cell integrity was investigated with a triple staining protocol, focusing on the mitochondrial networks, the cytoskeleton and the nucleus [12,51]. A. sativum is widely used for its antibacterial, antifungal, anti-inflammatory, and antitumoral properties, especially due to its organosulfur compounds [4,10,20,45]. Garlic extract showed a growth inhibitory effect after $24 \mathrm{~h}$ exposure to $100 \mathrm{mg} / \mathrm{mL}$ (equivalent to $10 \%$ extract), cell death aspects were visible, as presented in Figure 3D,H, the cytoskeleton collapsed, on BJ cells the nucleus was slightly visible, moreover the mitochondrial networks were not visible and the cell density was significantly reduced compared to the control group (Figure 3A). At the $\mathrm{IC}_{50}$ concentration $(0.8841 \%$ for $\mathrm{BJ}$ and $1.086 \%$ for $\mathrm{HaCaT})$ for both $\mathrm{BJ}$ and HaCaT cells the cytoskeleton networks showed minor damage and the cellular shape was modified (Figure 3C,G). At concentrations below $\mathrm{IC}_{50}(0.5 \%$ for $\mathrm{BJ}$ and $0.1 \%$ for HaCaT) the cytoskeleton was not damaged, while the mitochondrial networks were visible and the morphological characteristics (Figure 3B,F) were comparable with the control group. $\mathrm{HaCaT}$ cells showed particular changes in mitochondrial networks at $5 \mathrm{mg} / \mathrm{mL}$ treatment with an intensified activity compared to the control group.

As presented in Figure 3, A. sativum extract inhibited cell growth in a dose dependent manner, this effect could be attributed to the complex mixture of bioactive compounds and due to the hydroalcoholic composition of the extract, thus inducing cellular stress.

A. fistulosum is a common Allium plant in Eastern Europe, rich in sulfur compounds and sterols, with antibacterial and antifungal properties [43]. As presented in Figure 4, at the highest dose of Welsh onion extract $(83 \mathrm{mg} / \mathrm{mL})$ induced cell death in both cell lines, the cytoskeleton was completely damaged, the mitochondrial networks and the nucleus were unclear and damaged (Figure 4D,H). At the $\mathrm{IC}_{50}$ dose, $2.019 \mathrm{mg} / \mathrm{mL}$ for BJ and $5.144 \mathrm{mg} / \mathrm{mL}$ for HaCaT, the cytoskeleton showed moderate damage, with focal adhesion points at HaCaT cells, which might be visible due to the usual distribution of these cells in small groups, with strong connections between cells (Figure $4 \mathrm{C}, \mathrm{G}$ ). When adding $1 \mathrm{mg} / \mathrm{mL}$ of the extract on both cell lines (Figure $4 \mathrm{~B}, \mathrm{~F}$ ), the cytoskeleton showed minor damage, the mitochondrial networks were visible, and the cell distribution and shape were comparable with the control group.

Welsh onion extract had a cytotoxic effect in a dose dependent manner, with small differences between the selected cell lines, BJ cells being more affected by the treatment compared with $\mathrm{HaCaT}$; moreover, $\mathrm{HaCaT}$ cells had active mitochondrial networks highlighted at $1 \mathrm{mg} / \mathrm{mL}$ dose, while BJ cells had minor cytoskeleton damage and few mitochondrial networks with higher intensity (Figure 4).

The most cytotoxic concentration seems to be the $10 \%$ Welsh onion extract where the cytoskeleton was disrupted and the nucleus was almost gone and the mitochondrial network was not as usual but was still visible for BJ cells and for $\mathrm{HaCaT}$ cells no mitochondria network could be highlighted ( $\mathrm{D}$ for $\mathrm{BJ}$ and $\mathrm{H}$ for $\mathrm{HaCaT}$ ). The $\mathrm{IC}_{50}$ concentration for both cell lines had no cytotoxic effect; the nucleus and cytoskeleton were very well highlighted, and the mitochondrial network seemed to be very active ( $\mathrm{C}$ for $\mathrm{BJ}$ and $\mathrm{G}$ for HaCaT). Cell structure and the morphological characteristics for cells that were treated with a lower extract dose than $\mathrm{IC}_{50}$ ( $\mathrm{B}$ for $\mathrm{BJ}$ and $\mathrm{F}$ for $\mathrm{HaCaT}$ ) were comparable with the control group (A for BJ and $\mathrm{E}$ for $\mathrm{HaCaT}$ ).

The highest concentrations that were used $(10 \%, 5 \%$, and $2.5 \%$ extract) were the most cytotoxic, cytoskeleton modifications were induced, and the cell shape was different compared to the control. Moreover, mitochondrial networks were less intense than control and the nucleus for treated cells with $100 \mathrm{mg} / \mathrm{mL}$ garlic extract and $86 \mathrm{mg} / \mathrm{mL}$ Welsh onion extract was no more visible or slightly visible. Confocal images are leading us to say that Allium extracts at a higher dose than $\mathrm{IC}_{50}$ were inducing necrosis in normal fibroblasts and keratinocytes.

These images were indicating a cytotoxic effect for both extracts when concentration was high (10\% extract) and a lower cytotoxic effect when the extract concentration was reduced, morphological modification with the disrupted cytoskeleton and mitochondrial network was indicating that cell death was induced by necrosis in the group treated with 
$10 \%$ extracts, while at lower concentrations of extracts cell populations were less affected and the structural damage was highlighted in a dose-dependent manner.

\subsection{Biochemical Determination of LDH, CAT, and Caspase 3}

Caspase 3 is a key molecule in the apoptotic pathway, being the node between the intrinsic and extrinsic apoptotic pathway. Increased activity of active Caspase 3 (Casp3) is correlated with apoptotic cells [53]. Allium species can induce apoptosis due to their organosulfur compounds, which increase Bax/Bcl-2 ration and enhance Casp3 activity [54].

A. sativum and A. fistulosum extracts slightly increased the activity of Casp3 in both cell lines, with a pronounced effect on keratinocytes when all three doses had increased the Casp3 activity compared to the control (Figure 5). In order to confirm the apoptosis or the necrosis, the flow cytometry analysis should be taken into consideration, moreover, these results need to be correlated with lactate dehydrogenase (LDH) activity and catalase (CAT) activity for a complete understanding of the effect of both extracts on BJ and HaCaT cells.

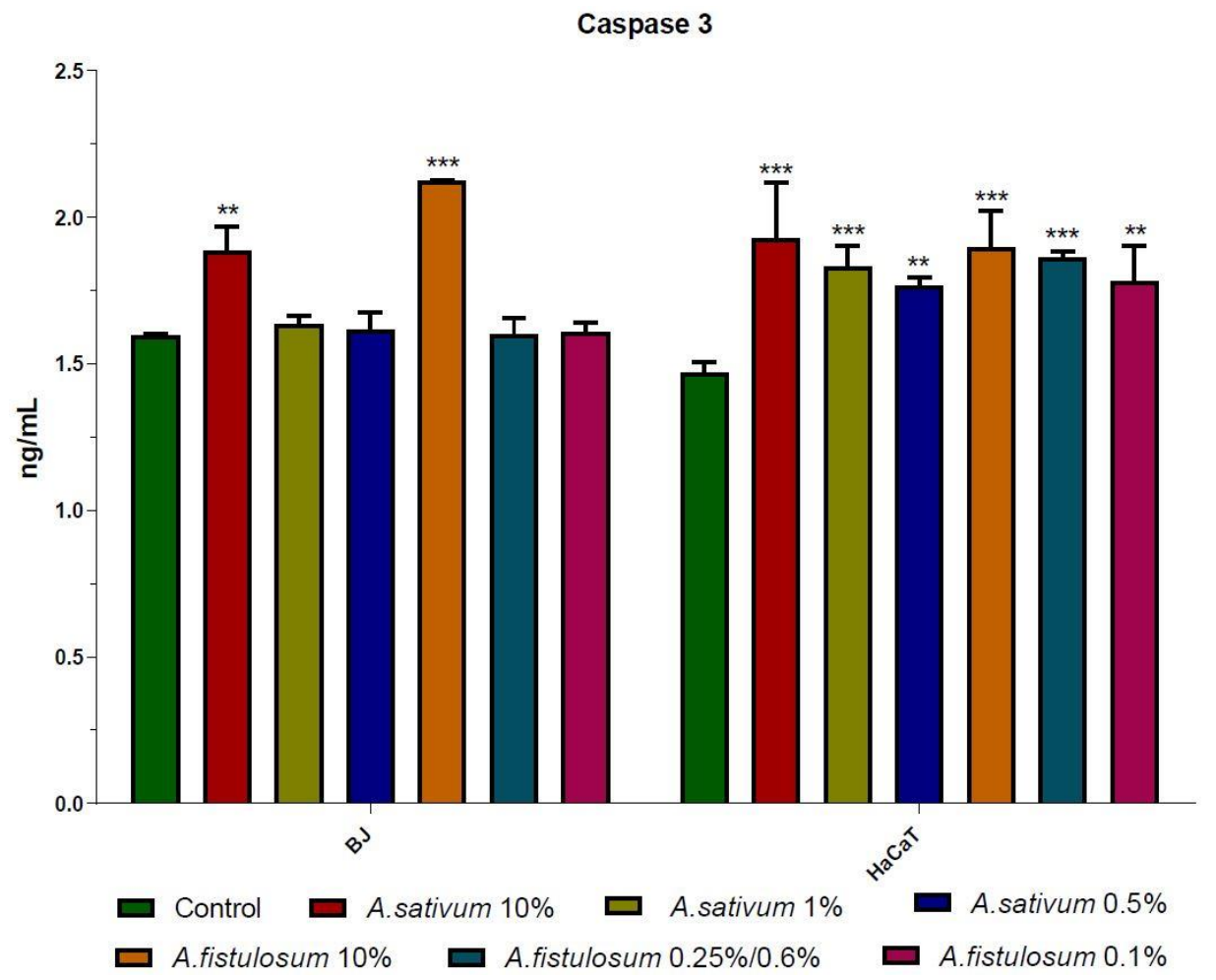

Figure 5. For BJ cells, increased Casp3 was observed for $10 \%$ Allium sativum extract $(100 \mathrm{mg} / \mathrm{mL})$ and for $10 \%$ A. fistulosum extract $(83 \mathrm{mg} / \mathrm{mL})$, while for other concentrations there was no difference compared to the control group. As for HaCaT cells Casp3 was activated in a dose-dependent manner compared with the control group. Even if the statistical significance was very high, the numeric value of Casp3 activity was not so high and the results must be correlated with other parameters analyzed. ** $p<0.01$, and ${ }^{* *} p<0.001$ when comparisons were made with the $C$ group.

To discriminate the necrosis and apoptosis, $\mathrm{LDH}$ and CAT activity were measured by colorimetric assay. Catalase is an important enzyme involved in cell protection against oxidative damage. CAT catalyzes the decomposition of $\mathrm{H}_{2} \mathrm{O}_{2}$ into $\mathrm{H}_{2} \mathrm{O}$ and $\mathrm{O}_{2}$ [55] Increased CAT activity is an indicator of increased oxidative stress, which may dysregulate normal physiological processes within the cells. An overexpressed CAT can reveal a high concentration of reactive oxygen species (ROS). Garlic extract has no effect on CAT activity in $\mathrm{BJ}$ cells at $10 \%$ of extract in the cell culture medium, while at $\mathrm{IC}_{50}$ concentration the CAT activity was increased in BJ cells. On the other hand, on HaCaT cells, at $10 \%$ of garlic extract, CAT activity was increased, and decreased at lower doses (Figure 6). In the case of Welsh 
onion extract, the effect was similar for both cell lines, at the highest concentration the CAT activity was increased, while at lower doses a decrease of CAT activity was observed.

\section{Catalase}

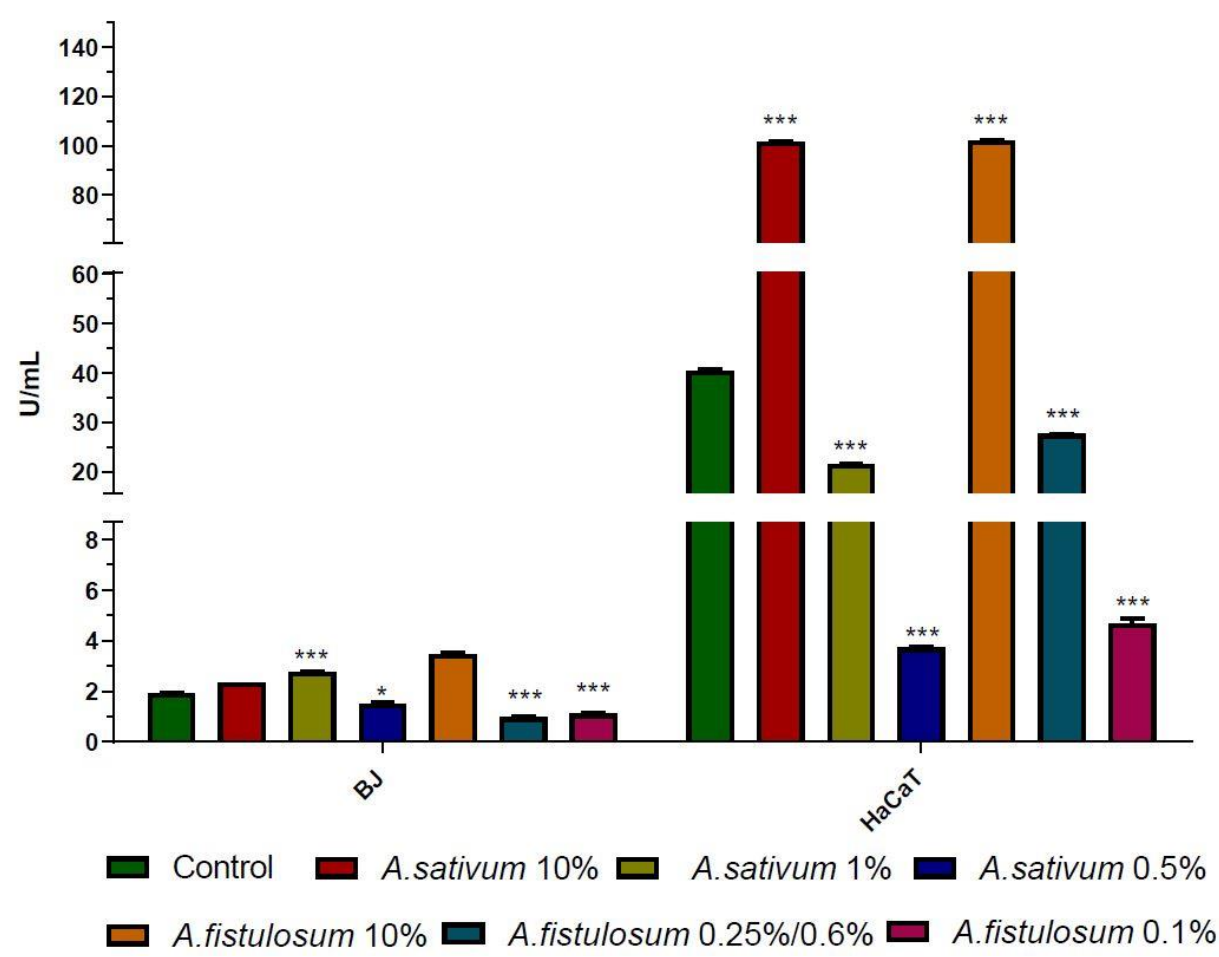

Figure 6. Catalase was increased around the $\mathrm{IC}_{50}$ value of Allium sativum extract in $\mathrm{BJ}$ cells ( $1 \%$ extract equivalent to $10 \mathrm{mg} / \mathrm{mL}$ ) and decreased in treatment with A. fistulosum; the numeric value of CAT activity is not so high, compared to HaCaT cells. Keratinocytes are more sensitive to A. sativum and $A$. fistulosum extract and the effect is different for each dose. ${ }^{*} p<0.05$ and ${ }^{* * *} p<0.001$ when comparisons were made with the $\mathrm{C}$ group.

At the highest dose, extracts acted like pro-oxidants and increased CAT activity, while around the $\mathrm{IC}_{50}$ and below the CAT activity was significantly lowered compared to the control group. These indicate that in a dose dependent manner, Allium extracts act differently depending on the cells that are used, moreover the shift between pro-oxidant and antioxidant effect can be made by changing the concentration of the extract that is used in the experiment. Increased CAT is correlated with high oxidative stress in cells. Lactate dehydrogenase (LDH) is a soluble enzyme located in the cytoplasm in almost all cells and it is released in the extracellular space when the plasma membrane is disrupted. Damaged membranes could be a marker for necrosis, moreover, during necrosis, the function and morphology of the organelles suffer changes, some of them have disrupted membranes or modified shape [56].

LDH release can be used as a marker for cytotoxicity; very active LDH in the supernatant is indicating that cell membranes have suffered modifications and cellular integrity was affected [41], both Allium extracts that were used in this study have a cytotoxic effect depending on the dose that was added as treatment, with a more pronounced cytotoxic effect for the Welsh onion extract. Furthermore, HaCaT cells seem to be more sensitive to the A. fistulosum extract than BJ cells, as presented in Figure 7.

Cells that were treated with $100 \mathrm{mg} / \mathrm{mL}$ garlic and $86 \mathrm{mg} / \mathrm{mL}$ Welsh onion had released a large amount of LDH in the culture medium and had CAT with an increased activity indicating that oxidative stress was harming the cells and was disrupting cell membrane causing cell death. Caspase 3 was not so intense in its activity in none of the cells. LDH and CAT that were increased were indicating that cells might be in necrosis. To 
confirm or not confirm the necrosis, Annexin V/PI was performed, or samples were treated with the highest dose of $50 \mathrm{mg} / \mathrm{mL}$ garlic extract and $43 \mathrm{mg} / \mathrm{mL}$ Welsh onion extract. The results were encouraging us to confirm that Allium extracts had cytotoxic effects by inducing necrosis in treated cells in a dose-dependent manner and with a different intensity in BJ cells compared to HaCaT cells.

\section{LDH}

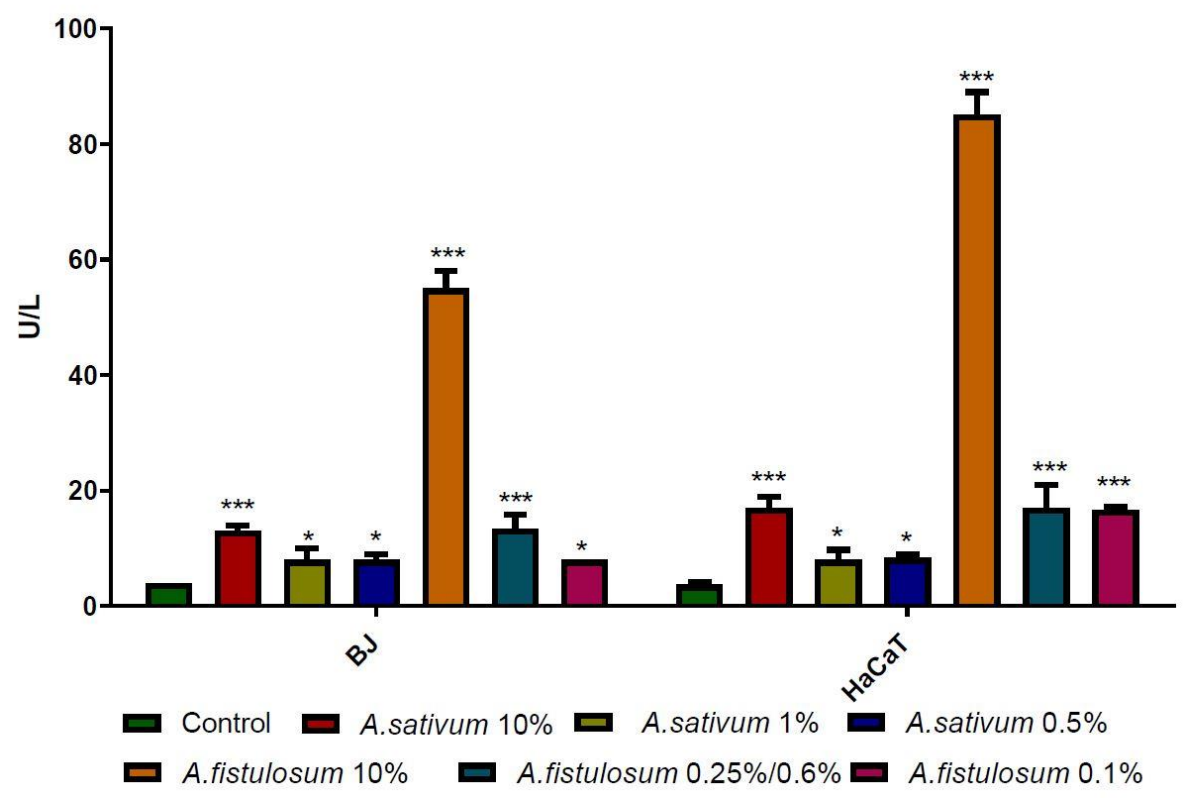

Figure 7. For both cell lines, Allium sativum and A. fistulosum extracts enhanced LDH activity in a dose dependent manner, with the most intensified activity for the $10 \%$ of extract compared with the control group. A. fistulosum increased LDH activity more than garlic extract in both cell lines, indicating that the chemical composition of the extracts is a very important player in how different molecules are modulated. ${ }^{*} p<0.05$ and ${ }^{* *} p<0.001$ when comparisons were made with the $C$ group.

Doses between 0.062 and $1 \mathrm{mg} / \mathrm{mL}$ were used to investigate the ROS production after exposing the SCC-15 cell line to A. sativum extract, with results indicating a dose-dependent increasing ROS production, correlated with an increased LDH activity [41], similar to herein presented results on the LDH activity trend.

\subsection{The Evaluation of Induced Cell Death}

For completing the confocal images information and to characterize which type of cell death was induced in BJ and HaCaT cell lines, biochemical analysis, Caspase 3 quantification, and Annexin/PI Flow Cytometry Assay are coming to underline the effect of $A$. satioum and $A$. fistulosum extracts.

Annexin V/PI Assay is a golden standard assay to determine the percentage of viable, necrotic, or apoptotic cells. Untreated cells from HaCaT negative control group were 95\% viable with $5 \%$ necrotic cells, while the positive control for $\mathrm{HaCaT}$ cells had $88.6 \%$ viable cells, $10.8 \%$ necrotic, $0.4 \%$ early apoptotic, and $0.2 \%$ late apoptotic cells. Necrosis was induced in a dose dependent manner in $\mathrm{HaCaT}$ cells by the A. sativum extract with the most intense necrosis for the $5 \%$ concentration $(6.1 \%$ necrotic cells and $93.9 \%$ viable) and by the $A$. fistulosum extract with $7.9 \%$ necrotic cells at the sample treated with $5 \%$ extract. It is interesting that for HaCaT cells no apoptotic cell was detected, while for BJ cells only for the $0.5 \%$ garlic extract no apoptotic cell was detected. The negative control for BJ cells had $90.2 \%$ viable cells, $9.7 \%$ necrotic cells, and $0.1 \%$ late apoptotic cells, while the positive control had $84 \%$ viable and $16 \%$ necrotic cells. The most aggressive treatment was the $5 \%$ A. satioum extract with $19.3 \%$ necrotic cells, $0.1 \%$ early apoptotic, and $0.4 \%$ late apoptotic cells; moreover the $A$. fistulosum extract at $5 \%$ concentration in cell culture 
media induced necrosis in $16.8 \%$ of the cells and $0.5 \%$ late apoptosis. It is true that at the $\mathrm{IC}_{50}$ concentration, both garlic ( $1 \%$ extract concentration) and Welsh onion $(0.25 \%$ extract concentration) induced early apoptosis, $1.6 \%$ for $\mathrm{BJ}$ treated with garlic at $\mathrm{IC}_{50}$ concentration and $2.6 \%$ early apoptosis and $1 \%$ late apoptosis for $\mathrm{BJ}$ treated with the Welsh onion extract at $\mathrm{IC}_{50}$ concentration. However, concentrations below $\mathrm{IC}_{50}$ had a less toxic effect, moreover, all concentrations that were used kept cell viability above $80 \%$.

Garlic and Welsh onion extracts induced necrosis, according to the Annexin V/PI flow cytometry assay, with a very low rate of induced apoptosis. In Figure 8 it could be observed very clearly how both extracts reduced cell viability (dark green plots) and how intense is the necrosis (red plots), moreover the light blue plots indicate early apoptosis and light green plots late apoptosis, showing the massive difference between necrotic and apoptotic cell number, moreover, it indicates that the cell death morphological aspects and the elevated LDH activity at high concentrations of extracts were related to cell death by necrosis.

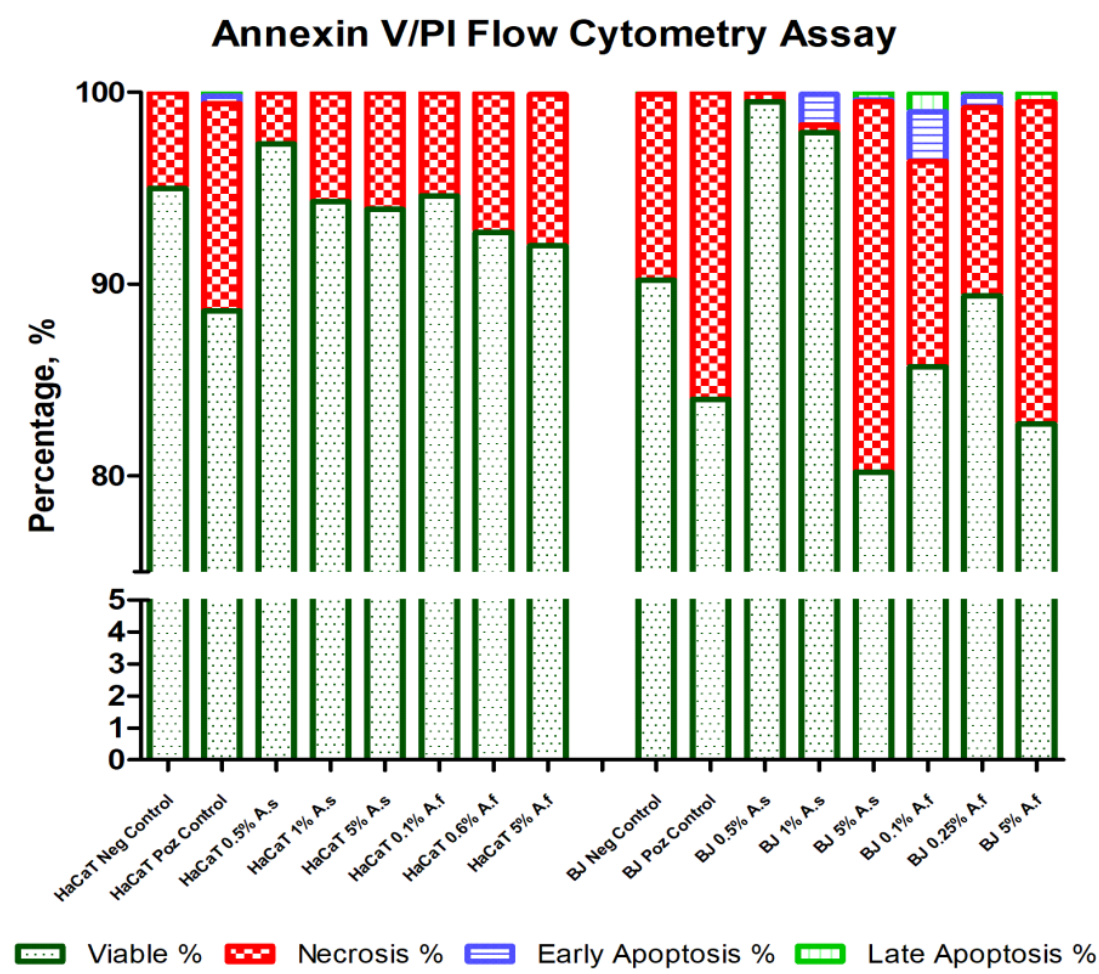

(A)

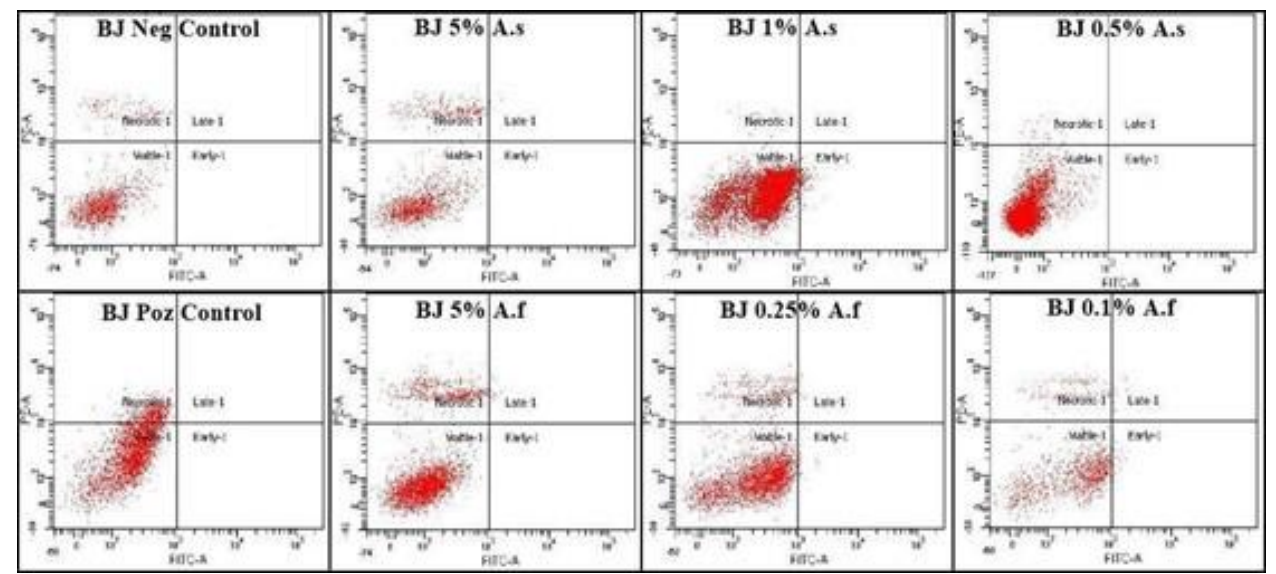

(B)

Figure 8. Cont. 


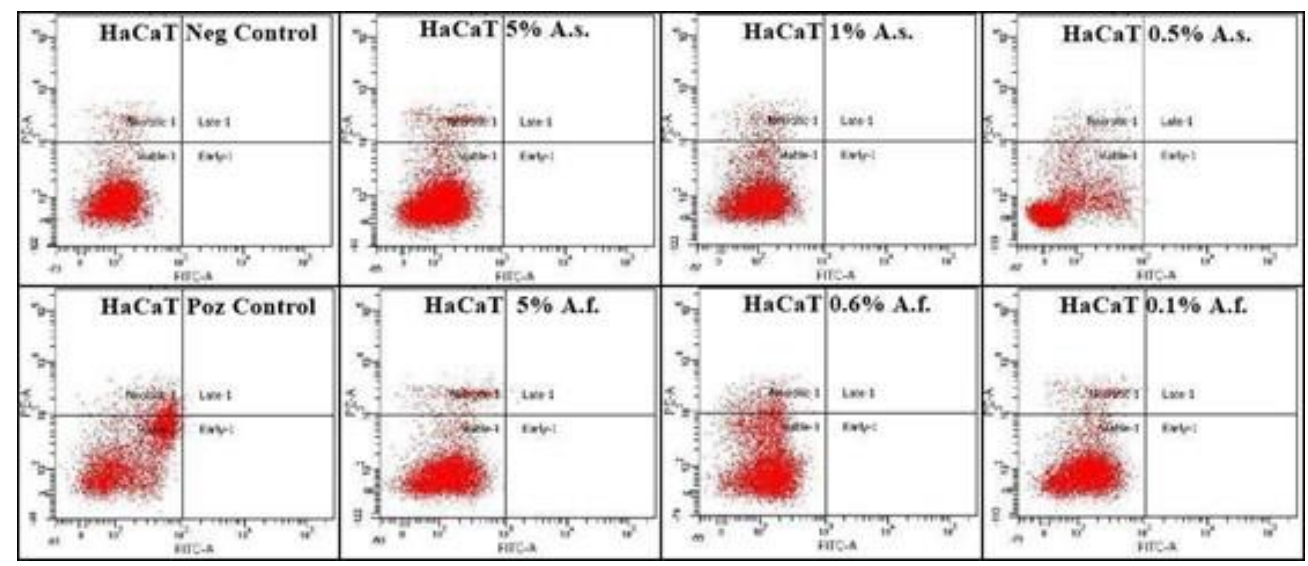

(C)

Figure 8. Annexin V/PI Flow Cytometry Assay for BJ and HaCaT cell lines treated with different concentrations of Allium sativum and A. fistulosum extracts. Annexin V and PI were added to each sample. Negative controls were not treated with extracts and positive controls were supplemented with DMSO at a final volume of $10 \%$ in growth media. All extract concentrations were selected to be similar to other concentrations that were used for other determinations. Both cell lines were incubated for $24 \mathrm{~h}$ with certain Allium extracts. (A)—graph representing population percentages; (B)—BJ scatter plot; (C)—HaCaT scatter plot. A.s—Allium sativum; A.f.—Allium fistulosum; Neg Control-negative control; Poz Control-positive control.

\subsection{Antiproliferative Effect on Tumor Cells}

Different concentrations of $A$. sativum and A. fistulosum extracts were investigated for their potential antiproliferative effect on four tumor cell lines, colorectal cancer cells (DLD1), breast cancer cells (MDA-MB-231 and MCF-7), and lung carcinoma cells (SK-MES-1). For garlic hydroalcoholic extract, concentrations between $10 \%$ and $0.156 \%$ extract in cell culture medium were analyzed (Figure 9), while for Welsh onion extract the concentrations were between $2.5 \%$ and $0.156 \%$ (Figure 10), when adding $5 \%$ and $10 \%$ extract in the cell culture medium, we observed color change due to the $\mathrm{pH}$ indicator. We excluded those values from our analysis.

The $\mathrm{IC}_{50}$ for both Allium extracts were higher than $1.25 \%$ extract (equivalent to more than $1 \mathrm{mg} / \mathrm{mL}$ ). A. sativum extract had IC 50 values of $4.651 \%$ for SK-MES-1, which was the most sensitive cell line to garlic extract, 5.482\% for DLD-1, 6.131\% for MCF-7, and 6.375\% for MDA-MB-231, which was the less sensitive cell line to garlic extract. Welsh onion extract had $\mathrm{IC}_{50}$ values of $2.124 \%$ for DLD-1 which is the most sensitive cell line to Welsh onion extract, $2.464 \%$ for MDA-MB-231, 3.353\% for MCF-7, and 5.819\% for SK-MES-1, which was the less sensitive cell line to Welsh onion. This value indicates that the extracts were concentrated in bioactive compounds, which might inhibit tumor cells, furthermore the extracts had a dose-dependent inhibitory effect on tumor cells. Alliin and allicin were the main compounds in both Allium extracts, the inhibitory effects were different and the inhibition rate was proportional with the concentration of extract added to the cells. The bioactive sulfuric compounds such as allicin and allyl sulfides have an antitumoral effect and are responsible for the growth inhibition of the studied tumor cells [4,57-59].

Allium extract used as a treatment, at a certain concentration can become cytotoxic for cells. At lower doses, no toxicity was observed on normal human cells. Allium extracts, particularly garlic, were investigated for their biological properties such as antioxidative [60,61], anti-inflammatory [62], antitumoral [63], antibacterial [64], and other biological properties due to their chemical composition.

The antiproliferative effect of $A$. sativum and $A$. fistulosum extracts was focused on active compounds within their composition and was highlighted in a dose-dependent manner. 


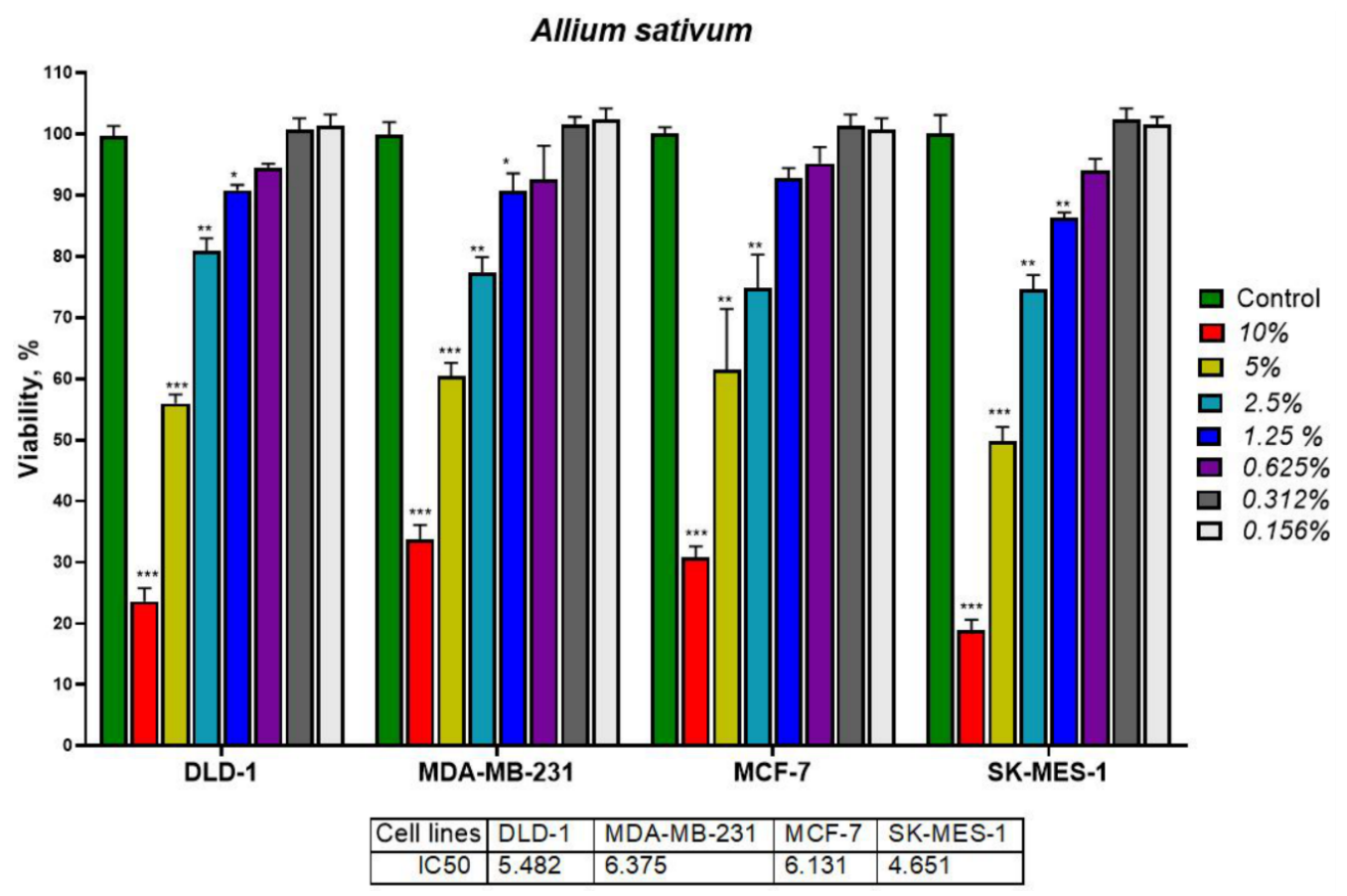

Figure 9. MTT assay for DLD-1, MDA-MB-231, MCF-7, and SK-MES-1 cell lines treated with different concentrations of Allium sativum extract. The results were expressed as ${ }^{*} p<0.05,{ }^{* *} p<0.01$, and ${ }^{* *} p<0.001$ with Student's $t$-test by comparison with control group (untreated). The samples treated with $10 \%$ extract in the culture medium (equivalent to $100 \mathrm{mg} \mathrm{mL}^{-1}$ ) showed highly significant inhibition, with a significant inhibitory effect even at 1\% extract. SK-MES-1 was the most sensitive cell line with $4.651 \%$ extract as the $\mathrm{IC}_{50}$ value (equivalent to $46 \mathrm{mg} / \mathrm{mL}$ ) and MDA-MB-231 the triple negative breast cancer cell line being the less sensitive cell line with $6.375 \%$ extract (equivalent to $63 \mathrm{mg} / \mathrm{mL}$ ) as the $\mathrm{IC}_{50}$ value.

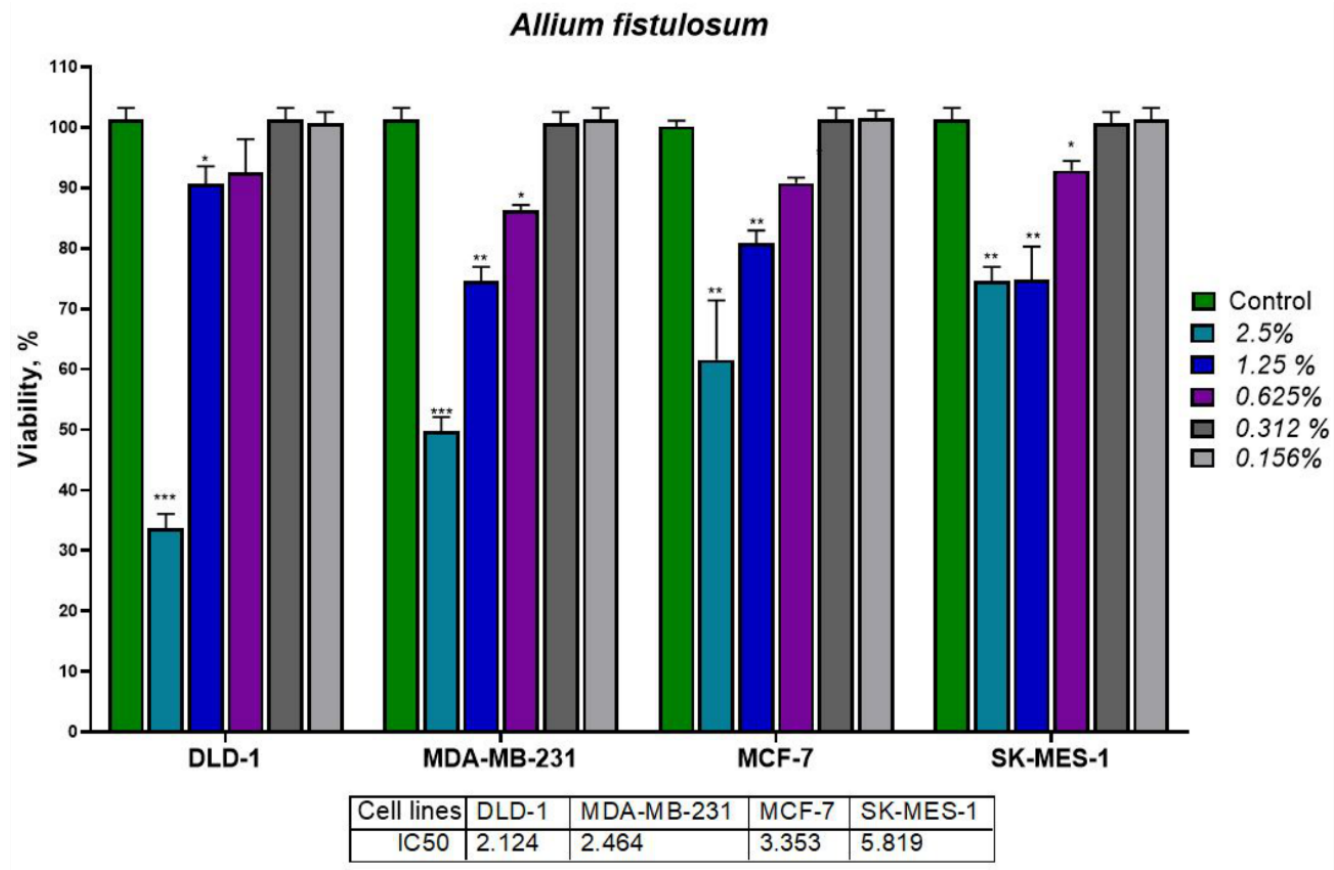

Figure 10. MTT assay for DLD-1, MDA-MB-231, MCF-7, and SK-MES-1 cell lines treated with different concentrations of Allium fistulosum extract. The results were expressed as ${ }^{*} p<0.05,{ }^{* *} p<0.01$, and ${ }^{* * *} p<0.001$ with Student's $t$-test by comparison with the control group (untreated). Due to the $\mathrm{pH}$ changes induced by the $10 \%$ and $5 \%$ concentrations in the cell culture medium observed by the phenol red color change, the MTT assay was performed between $2.5 \%$ and $0.156 \%$ extract. The $\mathrm{IC}_{50}$ values were between $5.819 \%$ extract in cell culture medium for SK-MES-1 and $2.123 \%$ extract in cell culture medium for DLD-1 cell line. 
It was demonstrated that both Allium extracts have an immunostimulatory effect [65] mostly due to their sulfur bioactive compounds, like allicin [19], being a possible therapeutical approach for alternative antitumor therapy. Further investigations and optimization of the therapeutic dose should be taken into consideration, moreover, a multidose experiment could present interest in investigating the antitumoral effect of Allium extracts and comparing the effects with their bioactive compounds and conventional therapeutical agents.

Allicin has the potential to play a role in antitumor therapies as lung, breast, and colorectal carcinoma [12,20]. Our previously published results indicate that the bioactive sulfuric compound can inhibit tumor cell proliferation, colony formation, and migration, moreover it can induce cell death by triggering apoptotic and non-apoptotic pathways [12] In the last years, many researchers have demonstrated the in vitro antitumoral potential of allicin, which can inhibit human renal cell carcinoma via the HIF pathway [66], can inhibit thyroid cancer progression [67], can suppress migration and invasion in cervical cancer cells [68], or can sensitize hepatocellular cancer cells to the antitumor activity of cytostatic drugs like 5-fluorouracil [69].

A. satioum extract had $380 \mu \mathrm{g} / \mathrm{mL}$ allicin, while $A$. fistulosum had $20 \mu \mathrm{g} / \mathrm{mL}$ allicin. The antiproliferative effect of both extracts might be attributed to allicin, which was the main bioactive compound in Allium extracts. At the $\mathrm{IC}_{50}$ values, allicin was present at a concentration of $19 \mu \mathrm{g} / \mathrm{mL}$ equivalent for $5 \%$ A. sativum extract and at concentrations between 0.2 and $1 \mu \mathrm{g} / \mathrm{mL}$ equivalent for $2-5 \%$ A. fistulosum extract.

The antiproliferative effect of both Allium extracts was visible in a dose-dependent manner, depending on the concentration of the main bioactive compound, allicin. Other studies revealed that allicin has an antiproliferative effect against tumor cells at different concentrations, depending on the cell type. Allicin showed an inhibitory effect against U251 cells at an $\mathrm{IC}_{50}$ of $41.97 \mu \mathrm{g} / \mathrm{mL}$ [70]; $10.38 \mu \mathrm{g} / \mathrm{mL}$ against SK-Hep-1 cells; and $10.00 \mu \mathrm{g} / \mathrm{mL}$ against BEL-7402 cells [69]. In our previous study, allicin inhibited SK-MES-1 cells at an $\mathrm{IC}_{50}$ of $1.39 \mu \mathrm{g} / \mathrm{mL}$ (equivalent to $8.6 \mu \mathrm{M}$ ) and DLD-1 cells at $\mathrm{IC}_{50}$ of $8.67 \mu \mathrm{g} / \mathrm{mL}$ (equivalent to $53.53 \mu \mathrm{M}$ ) [12]. Besides, allicin showed a synergistic effect when combined with 5-fluorouracil on DLD-1 and SK-MES-1 [12].

The antiproliferative effect of allicin from Allium extracts is completed by the phenolic compounds [2,18]. Moreover, glucoside quercetin has an important role in the antiproliferative effect of $A$. sativum, A. fistulosum, A. cepa, and A. chinense extracts against HepG2, PC-3, and HT-29 cell lines [69]. The dose-dependent inhibitory effect of $A$. sativum and $A$. fistulosum extracts is related to the concentration of allicin. Gruhlke et al. evaluated the inhibitory effect of allicin in garlic juice and synthesized allicin on lung adenocarcinoma (A549 cell line), human mammary carcinoma (MCF-7 cell line), human colorectal carcinoma (HT29 cell line), mouse fibroblasts (NIH 3T3 cell line), and human umbilical vein endothelial cells (HUVEC) and the results indicate an inhibitory rate on all cell lines, in a dose-dependent manner [20]. Furthermore, Allium extracts are rich in polyphenols, which play important role in the biological effects of garlic and Welsh onion. The antitumor effect of both Allium extracts is mainly attributed to allicin, while polyphenols are enhancing this biological effect. Fujimoto et al. demonstrated that polyphenols have a cytotoxic effect in a dose-dependent manner both on normal and tumor cells, and at a well-established concentration, polyphenols could inhibit tumor cell without affecting normal cells [71].

Polyphenols, in a dose-dependent manner, can induce cell death by inducing apoptosis [71]. Sulfuric compounds, like allicin, have a different effect on cell signaling pathways. Allicin inhibits cell growth and induces apoptosis via the ERK-dependent pathway [31] or can activate both intrinsic and extrinsic apoptotic pathways [25,33,70]. Moreover, allicin can inhibit tumor cell progression by suppressing the HIF pathway [66]. Allicin suppresses cervical cancer cells invasion and migration via inhibiting $\mathrm{NRF}_{2}$ [68]. Furthermore, allicin has an immunostimulatory effect via Colec12, MARCO, and SCARB1 receptors [19]. A similar proapoptotic effect was observed in the case of diallyl trisulfides, which are part of Allium plants' chemical composition, Shin et al. demonstrated that diallyl trisulfides 
induce apoptosis in caspase-dependent manner and create cross-talks with PI3K/Akt and JNK pathways [58].

Both Allium extracts that were investigated in our study were rich in allicin and polyphenols and showed an inhibitory effect in a dose-dependent manner both on normal and tumor cells. At high concentrations, above the concentration obtained for the $\mathrm{IC}_{50}$, cell damage was induced and the LDH and CAT activity was increased. On the other hand, at lower concentrations the cellular stress was reduced, LDH and CAT activity were significantly decreased compared to the $10 \%$ extract. The inhibitory effect was related to the chemical composition of the extracts. The cytotoxicity could be reduced by choosing a therapeutic dose that is not toxic to normal cells and by isolating or synthesizing bioactive compounds from the extracts, compounds that are responsible for the biological effect of these plants.

Further investigations are needed to evaluate the therapeutical potential of Allium extracts and their bioactive compounds, focusing on the molecular links between the active compounds and the effector molecules in eukaryotic cells.

\section{Materials and Methods}

\subsection{Plant Material and Growth Conditions}

Garlic (Allium sativum L.) plants were cultivated in a private garden [10] and Welsh onion (Allium fistulosum L.) plants in the Botanical Garden "Alexandru Borza" from luj-Napoca, Romania. For each Allium species, a voucher specimen was deposited at the Herbarium of Babes-Bolyai University, Cluj-Napoca, Romania (Allium sativum L.CL666161; Allium fistulosum L.-CL 669061).

\subsection{Allium Extract Preparation}

Different parts of the plants were used for the extract preparation, leaves for Allium fistulosum and bulbs for $A$. sativum. The cold repercolation method at room temperature for 3 days was used for preparing Allium plant extract [47] from small plant fragments $(0.5-1 \mathrm{~cm})$ and $70 \%$ ethanol (Merck, Bucharest, Romania).

The fluid extract (w:v/g:mL) obtained by filtration was 1:1.2 with 30\% ethanol for $A$. fistulosum and 1:1 with 20\% ethanol for A. sativum. Data regarding the chemical composition of $A$. sativum extract was previously published by Pârvu et al. [53].

\subsection{Phytochemical Characterization of Extracts}

The phytochemical characterization was performed according to the method that was previously published by Pârvu et al. [6]. Two HPLC-DAD-MS protocols were optimized to separate and determine the main phytoconstituents as allicin and alliin and polyphenolic compounds [3]. Total phenolic content (TPC) was determined using the Folin Ciocalteu reagent [72] and total tiosulfinate content (TTC) by a kinetic assay previously described [72,73].

\subsection{Cells and Reagents}

The normal human fibroblasts cell line BJ, colorectal cancer cell line DLD-1, squamous cell lung carcinoma cell line SK-MES-1, triple negative breast cancer cell line MDA-MB-231, and double positive breast cancer cell line MCF-7 were purchased from the American Type Culture Collection (ATCC) (Manassas, VA, USA) and the normal human keratinocyte $\mathrm{HaCaT}$ was acquired from the Cell Line Service of the German Cancer Research Centre in Heidelberg, Germany. BJ and MCF-7 were maintained in minimum essential medium Eagle-MEM (Sigma Aldrich, ST. Louis, MI, USA), MDA-MB-231, DLD-1, and SK-MES-1 in RPMI (Sigma Aldrich, St. Louis, MI, USA), and HaCaT in Dulbecco's modified Eagle medium—DMEM with low glucose (Sigma Aldrich, St. Louis, MI, USA) [74,75], all supplemented with 10\% fetal bovine serum (Gibco, Grand Island, NY, USA), 1\% glutamine (Gibco, Grand Island, NY, USA), and 1\% penicillin-streptomycin (Gibco, Grand Island, NY, USA). 


\subsection{MTT Assay on Normal and Tumor Cells}

Cytotoxicity study of Allium extracts on normal and tumor cell lines were performed using MTT assay (Khazei et al., 2017). Cells were plated at $1 \times 10^{4}$ cells per well in a 96-well plate. After $24 \mathrm{~h}$ of incubation, cells were treated with A. sativum and A. fistulosum extract and incubated for $24 \mathrm{~h}$ at $37^{\circ} \mathrm{C}$ in a humidified incubator with $5 \% \mathrm{CO}_{2}$. After $24 \mathrm{~h}$, the cell viability rate was determined using a 3-(4,5-dimethylthiazol-2-yl)-2,5-diphenyltetrazolium bromide (MTT) assay at $570 \mathrm{~nm}$ (Sigma-Aldrich, St. Louis, MI, USA). The plates were read with a TECAN SPARK10M (TECAN, Austria GmbH, Grodig, Austria).

The cell viability was calculated by the following equation: $\%$ Cytotoxicity $=\mathrm{Ab}$ sorbance of treated cells / Absorbance of negative control $\times 100$. The $50 \%$ of the growth inhibition concentration $\left(\mathrm{IC}_{50}\right)$ was calculated from a plotted dose-response curve [36].

\subsection{Confocal Microscopy-Morphological Analysis}

Cells were processed following a triple staining protocol in order to highlight the mitochondrial networks, the cytoskeleton and the nucleus, using Mitotracker-Red, PhalloidinFITC, and DAPI according to the protocol that was previously published by Budisan et al. [51]. Mitotracker (Thermo Fisher Scientific, Waltham, MS, USA) was added while the cells were still viable, after $90 \mathrm{~min}$ of incubation at $37^{\circ} \mathrm{C}$ the cells were fixed with $4 \%$ paraformaldehyde (Sigma-Aldrich, St. Louis, MI, USA) and the membranes were treated with $0.05 \%$ Triton X (Sigma-Aldrich, St. Louis, MI, USA). After Triton X treatment, Phalloidin-FITC (Cytoskeleton, Denver, CO, USA) was added and the samples were incubated for $30 \mathrm{~min}$ at room temperature. After Phalloidin incubation, $100 \mu \mathrm{M}$ DAPI solution (Thermo Fisher Scientific, Waltham, MS, USA) was added for one minute. Between each step the cells were washed three times with phosphate saline buffer 1X (Gibco, Grand Island, NY, USA). Cells were analyzed under an Olympus FLUOVIEW FV1200 laser scanning fluorescence confocal microscope (Olympus, Tokyo, Japan).

\subsection{Biochemical Determination of LDH, CAT, and Caspase 3}

Cells were incubated at $1 \times 10^{5}$ cells per well in a 12-well plate at a final volume of $2000 \mu \mathrm{L}$. After $24 \mathrm{~h}$ incubation, cells were treated with extracts using three different concentrations $\left(10 \%\right.$ extract in the media, the $\mathrm{IC}_{50}$ concentration and one concentration below $\mathrm{IC}_{50}$ ). The supernatant was collected after $24 \mathrm{~h}$ incubation with extracts. To obtain the cell homogenate, $2000 \mu \mathrm{L}$ of fresh media was added to each well, then the plates were frozen and thawed three times to dissociate the cell membranes, and the cell extract was collected for further analysis. Lactate-dehydrogenase (LDH) and catalase (CAT) [76], from supernatant samples were analyzed. LDH activity was measured at $340 \mathrm{~nm}$ using the LDH Activity Kit for in-vitro use (Biomaxima, Lublin, Poland) and the samples were read with a spectrophotometer (Biochemical Systems International, Model 2000 Evolution, Arezzo, Italy). Catalase activity was measured from the supernatant at $240 \mathrm{~nm}$ using an UV-Vis VWR UV-1600PC spectrophotometer (VWR, Radnor, PA, USA). Caspase 3 (Casp3) was determined from the cell supernatant using Human Caspase-3 (Activated) ELISA Kit from Invitrogen (Carlsbad, CA, USA) and the plate was read using a TECAN SPARK10M (TECAN, Austria $\mathrm{GmbH}$, Grodig) according to the assay protocol and the results were calculated using Prism 8 software (San Diego, CA, USA).

\subsection{Cell Death Investigation by Flow Cytometry}

Cells were incubated at $5 \times 10^{4}$ cells per well in a 24-well plate at a final volume of $1500 \mu \mathrm{L}$. After $24 \mathrm{~h}$ incubation, cells were treated with extracts using three different concentrations ( $5 \%$ extract in the media, the $\mathrm{IC}_{50}$ concentration, and one concentration below $\left.\mathrm{IC}_{50}\right)$. For detaching cells, Trypsin-EDTA was used, and cells were washed three times with PBS1X, centrifuged and then the cells were resuspended in $200 \mu \mathrm{L}$ of binding buffer. Annexin V-FITC (ExBIO, Prague, Czech Republic) and propidium iodide (PI) were added according to the manufacturer's protocol, $5 \mu \mathrm{L}$ Annexin $\mathrm{V}$ and $5 \mu \mathrm{L}$ of propidium iodide then $15 \mathrm{~min}$ of incubation at room temperature was performed to allow staining. 
After incubation, cells were centrifuged and resuspended in $100 \mu \mathrm{L}$ of $1 \mathrm{X}$ annexin binding buffer and the samples were immediately read using a FACS BD Flow cytometer (BD, San Jose, CA, USA) and the results were calculated with Prism8 software.

\subsection{Statistical Analysis}

Viability rate was calculated using Prism 8 software, two-way ANOVA, and Bonferroni's post-hoc test was considered statistically significant at $p<0.05$ and was interpreted as follows: ${ }^{*} p<0.05,{ }^{* *} p<0.01$, and ${ }^{* * *} p<0.001$ when comparisons were made with the $C$ group. All the normal cells were compared to an untreated group as the control and the results were expressed as the mean value $\pm \mathrm{SD}$. The results were expressed as ${ }^{*} p<0.05$, ${ }^{* *} p<0.01$, and ${ }^{* *} p<0.001$ with Student's t-test by comparison with the control group (untreated) for the MTT assay on tumoral cells (GraphPad Software, San Diego, CA USA).

\section{Conclusions}

Allium sativum and A. fistulosum inhibited human fibroblasts and human keratinocytes growth when a high concentration of these extracts was applied. The MTT assay indicated a dose dependent growth inhibition for both extracts. Further observations of morphological changes in $\mathrm{BJ}$ and $\mathrm{HaCaT}$ cells, using a triple staining protocol, revealed the mitochondrial network, cytoskeleton, and nuclear modification, also the cell population was reduced in a dose dependent manner. Morphological modifications are indicators of the cell death induced by garlic and Welsh onion extracts at high doses of the extract. The flow cytometry analysis confirmed that cell death was induced at high extract concentrations, mostly by necrosis, correlating the results with the Casp3, LDH, and CAT analysis.

The extracts had different allicin concentrations, showing an antiproliferative effect against four tumor cell lines, with different $\mathrm{IC}_{50}$ values, depending on the concentration of allicin according to the phytochemical analysis of both extracts. We believe that the use of isolated bioactive sulfuric compounds, such as allicin, therefore can be used against tumor cells with promising results. We aim to develop further in vivo studies focused on the molecular interaction of allicin and other bioactive compounds with key molecules that control biological processes in the cells to determine the therapeutical potential of Allium bioactive compounds

Author Contributions: Conceptualization, A.B.T.; E.F.-F.; V.-A.T.; and M.P.; methodology, E.F.-F.; and M.P.; software, A.B.T.; validation, A.B.T.; C.S.M. and A.J.; formal analysis, A.B.T.; C.S.M.; A.C.M.; and M.P.; investigation, A.B.T.; and M.P.; resources, A.B.T.; V.-A.T.; A.D.F.; and M.P.; data curation, M.P.; writing—original draft preparation, A.B.T.; C.M.; and M.P.; writing—review and editing, A.B.T.; C.M.; and M.P.; visualization, M.P.; supervision, M.P.; project administration, A.B.T.; and M.P.; funding acquisition, M.P. All authors have read and agreed to the published version of the manuscript.

Funding: The publication of this article was supported by the 2020 Development Fund of the Babes-Bolyai University.

Institutional Review Board Statement: Not applicable.

Informed Consent Statement: Not applicable.

Data Availability Statement: Not applicable.

Acknowledgments: ABT and ACM are grateful to Romanian Ministry of Research, Innovation and Digitization for financial support, project PN-III-P1-1.1-TE-2019-1396.

Conflicts of Interest: The authors declare no conflict of interest.

Sample Availability: Samples of the compounds are available from the authors. 


\section{References}

1. Vimal, V.; Devaki, T. Hepatoprotective effect of allicin on tissue defense system in galactosamine/endotoxin challenged rats. J. Ethnopharmacol. 2004, 90, 151-154. [CrossRef] [PubMed]

2. Pan, Y.; Zheng, Y.M.; Ho, W.S. Effect of quercetin glucosides from Allium extracts on HepG2, PC-3 and HT-29 cancer cell lines. Oncol. Lett. 2018, 15, 4657-4661. [CrossRef] [PubMed]

3. Duke, J.A. Handbook of Medicinal Herbs, 2nd ed.; CRC Press: Boca Raton, FL, USA, 2002. [CrossRef]

4. Corzo-Martínez, M.; Corzo, N.; Villamiel, M. Biological properties of onions and garlic. Trends. Food. Sci. Technol. 2007, 18, 609-625. [CrossRef]

5. Shang, A.; Cao, S.Y.; Xu, X.Y.; Gan, R.Y.; Tang, G.Y.; Corke, H.; Mavumengwana, V.; Li, H.B. Bioactive Compounds and Biological Functions of Garlic (Allium sativum L.). Foods 2019, 8, 246. [CrossRef]

6. Banerjee, S.K.; Maulik, S.K. Effect of garlic on cardiovascular disorders: A review. Nutr. J. 2002, 1, 4. [CrossRef]

7. Ota, A.; Ulrih, N.P. An Overview of Herbal Products and Secondary Metabolites Used for Management of Type Two Diabetes. Front. Pharm. 2017, 8, 436. [CrossRef]

8. Isbilen, O.; Volkan, E. Allium Species in the Fight Against Cancer; MedDocs Publisher LLC: Reno, NV, USA, 2020.

9. D'Argenio, G.; Mazzone, G.; Ribecco, M.T.; Lembo, V.; Vitaglione, P.; Guarino, M.; Morisco, F.; Napolitano, M.; Fogliano, V.; Caporaso, N. Garlic extract attenuating rat liver fibrosis by inhibiting TGF- $\beta 1$. Clin. Nutr. 2013, 32, 252-258. [CrossRef]

10. Pârvu, M.; Moţ, C.A.; Pârvu, A.E.; Mircea, C.; Stoeber, L.; Roşca-Casian, O.; Tigigu, A.B. Allium sativum Extract Chemical Composition, Antioxidant Activity and Antifungal Effect against Meyerozyma guilliermondii and Rhodotorula mucilaginosa Causing Onychomycosis. Molecules 2019, 24, 3958. [CrossRef]

11. Iciek, M.; Kwiecień, I.; Włodek, L. Biological properties of garlic and garlic-derived organosulfur compounds. Environ. Mol. Mutagenesis 2009, 50, 247-265. [CrossRef]

12. Tigu, A.B.; Toma, V.-A.; Mot, A.C.; Jurj, A.; Moldovan, C.S.; Fischer-Fodor, E.; Berindan-Neagoe, I.; Pârvu, M. The Synergistic Antitumor Effect of 5-Fluorouracil Combined with Allicin against Lung and Colorectal Carcinoma Cells. Molecules 2020, $25,1947$. [CrossRef]

13. Rosas-González, V.C.; Téllez-Bañuelos, M.C.; Hernández-Flores, G.; Bravo-Cuellar, A.; Aguilar-Lemarroy, A.; Jave-Suárez, L.F.; Haramati, J.; Solorzano-Ibarra, F.; Ortiz-Lazareno, P.C. Differential effects of alliin and allicin on apoptosis and senescence in luminal A and triple-negative breast cancer: Caspase, $\Delta \Psi \mathrm{m}$, and pro-apoptotic gene involvement. Fundam. Clin. Pharm. 2020, 34, 671-686. [CrossRef]

14. Choi, Y.H.; Park, H.S. Apoptosis induction of U937 human leukemia cells by diallyl trisulfide induces through generation of reactive oxygen species. J. Biomed. Sci. 2012, 19, 50. [CrossRef] [PubMed]

15. Trio, P.Z.; You, S.; He, X.; He, J.; Sakao, K.; Hou, D.X. Chemopreventive functions and molecular mechanisms of garlic organosulfur compounds. Food Funct. 2014, 5, 833-844. [CrossRef] [PubMed]

16. Zimta, A.A.; Cenariu, D.; Irimie, A.; Magdo, L.; Nabavi, S.M.; Atanasov, A.G.; Berindan-Neagoe, I. The Role of Nrf2 Activity in Cancer Development and Progression. Cancers 2019, 11, 1755. [CrossRef] [PubMed]

17. Sobolewska, D.; Michalska, K.; Podolak, I.; Grabowska, K. Steroidal saponins from the genus Allium. Phytochem. Rev. 2016, 15, 1-35. [CrossRef] [PubMed]

18. Kothari, D.; Lee, W.D.; Kim, S.K. Allium Flavonols: Health Benefits, Molecular Targets, and Bioavailability. Antioxidants 2020, 9 , 888. [CrossRef]

19. Toma, V.A.; Tigu, A.B.; Farcaș, A.D.; Sevastre, B.; Taulescu, M.; Gherman, A.M.R.; Roman, I.; Fischer-Fodor, E.; Pârvu, M. New Aspects Towards a Molecular Understanding of the Allicin Immunostimulatory Mechanism via Colec12, MARCO, and SCARB1 Receptors. Int. J. Mol. Sci. 2019, 20, 3627. [CrossRef]

20. Gruhlke, M.C.; Nicco, C.; Batteux, F.; Slusarenko, A.J. The Effects of Allicin, a Reactive Sulfur Species from Garlic, on a Selection of Mammalian Cell Lines. Antioxidants 2016, 6, 1. [CrossRef]

21. Huang, L.; Song, Y.; Lian, J.; Wang, Z. Allicin inhibits the invasion of lung adenocarcinoma cells by altering tissue inhibitor of metalloproteinase/matrix metalloproteinase balance via reducing the activity of phosphoinositide 3-kinase/AKT signaling. Oncol. Lett. 2017, 14, 468-474. [CrossRef]

22. Chen, H.; Zhu, B.; Zhao, L.; Liu, Y.; Zhao, F.; Feng, J.; Jin, Y.; Sun, J.; Geng, R.; Wei, Y. Allicin Inhibits Proliferation and Invasion in Vitro and in Vivo via SHP-1-Mediated STAT3 Signaling in Cholangiocarcinoma. Cell. Phisiol. Biochem. 2018, 47, 641-653. [CrossRef]

23. Lanzotti, V.; Scala, F.; Bonanomi, G. Compounds from Allium species with cytotoxic and antimicrobial activity. Phytochem. Rev. 2014, 13, 769-791. [CrossRef]

24. Hirsch, K.; Danilenko, M.; Giat, J.; Miron, T.; Rabinkov, A.; Wilchek, M.; Mirelman, D.; Levy, J.; Sharoni, Y. Effect of purified allicin, the major ingredient of freshly crushed garlic, on cancer cell proliferation. Nutr. Cancer 2000, 38, 245-254. [CrossRef] [PubMed]

25. Oommen, S.; Anto, R.J.; Srinivas, G.; Karunagaran, D. Allicin (from garlic) induces caspase-mediated apoptosis in cancer cells. Eur. J. Pharm. 2004, 485, 97-103. [CrossRef] [PubMed]

26. Bat-Chen, W.; Golan, T.; Peri, I.; Ludmer, Z.; Schwartz, B. Allicin purified from fresh garlic cloves induces apoptosis in colon cancer cells via Nrf2. Nutr. Cancer 2010, 62, 947-957. [CrossRef]

27. Zhang, W.; Ha, M.; Gong, Y.; Xu, Y.; Dong, N.; Yuan, Y. Allicin induces apoptosis in gastric cancer cells through activation of both extrinsic and intrinsic pathways. Oncol. Rep. 2010, 24, 1585-1592. [CrossRef] 
28. Ha, M.W.; Yuan, Y. Allicin induced cell cycle arrest in human gastric cancer cell lines. Zhonghua Zhong Liu Za Zhi Chin. J. Oncol. 2004, 26, 585-589.

29. Zhang, Z.M.; Yang, X.Y.; Deng, S.H.; Xu, W.; Gao, H.Q. Anti-tumor effects of polybutylcyanoacrylate nanoparticles of diallyl trisulfide on orthotopic transplantation tumor model of hepatocellular carcinoma in BALB/c nude mice. Chin. Med. J. 2007, 120, 1336-1342. [CrossRef]

30. Park, S.Y.; Cho, S.J.; Kwon, H.C.; Lee, K.R.; Rhee, D.K.; Pyo, S. Caspase-independent cell death by allicin in human epithelial carcinoma cells: Involvement of PKA. Cancer Lett. 2005, 224, 123-132. [CrossRef]

31. Cha, J.H.; Choi, Y.J.; Cha, S.H.; Choi, C.H.; Cho, W.H. Allicin inhibits cell growth and induces apoptosis in U87MG human glioblastoma cells through an ERK-dependent pathway. Oncol. Rep. 2012, 28, 41-48. [CrossRef]

32. Arditti, F.D.; Rabinkov, A.; Miron, T.; Reisner, Y.; Berrebi, A.; Wilchek, M.; Mirelman, D. Apoptotic killing of B-chronic lymphocytic leukemia tumor cells by allicin generated in situ using a rituximab-alliinase conjugate. Mol. Cancer 2005, 4, 325-331.

33. Miron, T.; Wilchek, M.; Sharp, A.; Nakagawa, Y.; Naoi, M.; Nozawa, Y.; Akao, Y. Allicin inhibits cell growth and induces apoptosis through the mitochondrial pathway in HL60 and U937 cells. J. Nutr. Biochem. 2008, 19, 524-535. [CrossRef] [PubMed]

34. Vemuri, S.K.; Banala, R.R.; Gpv, S.; Av, G.R.; Thekkumalai, M. Apoptotic efficiency of aqueous extracts of turmeric, garlic and their active compounds in combination with Tamoxifen in lung and oral cancers: A comparative study. Beni-Suef Univ. J. Basic Appl. Sci. 2018, 7, 184-197. [CrossRef]

35. Khazaei, S.; Abdul Hamid, R.; Ramachandran, V.; Mohd Esa, N.; Pandurangan, A.K.; Danazadeh, F.; Ismail, P. Cytotoxicity and Proapoptotic Effects of Allium atroviolaceum Flower Extract by Modulating Cell Cycle Arrest and Caspase-Dependent and p53-Independent Pathway in Breast Cancer Cell Lines. eCAM 2017, 2017, 1468957. [CrossRef] [PubMed]

36. Khazaei, S.; Esa, N.M.; Ramachandran, V.; Hamid, R.A.; Pandurangan, A.K.; Etemad, A.; Ismail, P. In vitro Antiproliferative and Apoptosis Inducing Effect of Allium atroviolaceum Bulb Extract on Breast, Cervical, and Liver Cancer Cells. Front. Pharm. 2017, 8, 5. [CrossRef] [PubMed]

37. Gholipour, N.; Mashjoor, S.; Naderi, M.; Pouyani, M.R.; Tubkanlu, Z.E.; Samaei, N.M.; Khajeh, H. In vitro cytotoxic and apoptotic activities of Allium paradoxum (M. bieb.) G. Don extract on human breast cancer cell line. Indian J. Tradit. Knowl. 2018, 17, 247-254.

38. Isbilen, O.; Rizaner, N.; Volkan, E. Anti-proliferative and cytotoxic activities of Allium autumnale P. H. Davis (Amaryllidaceae) on human breast cancer cell lines MCF-7 and MDA-MB-231. BMC Complement Altern. Med. 2018, 18, 30. [CrossRef]

39. Perez-Ortiz, J.M.; Galan-Moya, E.M.; de la Cruz-Morcillo, M.A.; Rodriguez, J.F.; Gracia, I.; Garcia, M.T.; Redondo-Calvo, F.J. Cost Effective Use of a Thiosulfinate-Enriched Allium sativum Extract in Combination with Chemotherapy in Colon Cancer. Int. J. Mol. Sci. 2020, 21, 2766. [CrossRef]

40. Jasamai, M.; Hui, C.S.; Azmi, N.; Kumolosasi, E. Effect of Allium sativum (garlic) methanol extract on viability and apoptosis of human leukemic cell lines. Trop. J. Pharm. Res. 2016, 15, 1479-1485. [CrossRef]

41. Szychowski, K.A.; Binduga, U.E.; Rybczyńska-Tkaczyk, K.; Leja, M.L.; Gmiński, J. Cytotoxic effects of two extracts from garlic (Allium sativum L.) cultivars on the human squamous carcinoma cell line SCC-15. Saudi J. Biol. Sci. 2018, 25, 1703-1712. [CrossRef]

42. Ohkubo, S.; Dalla Via, L.; Grancara, S.; Kanamori, Y.; García-Argáez, A.N.; Canettieri, G.; Arcari, P.; Toninello, A.; Agostinelli, E. The antioxidant, aged garlic extract, exerts cytotoxic effects on wild-type and multidrug-resistant human cancer cells by altering mitochondrial permeability. Int. J. Oncol. 2018, 53, 1257-1268. [CrossRef]

43. Vlase, L.; Parvu, M.; Parvu, A.E.; Toiu, A. Phytochemical analysis of Allium fistulosum 1. and A. ursinum 1. Dig. J. Nanomater. Biostruct. 2013, 8, 457-467.

44. Park, H.S.; Choi, E.J.; Lee, J.-H.; Kim, G.-H. Evaluation of Allium Vegetables for Anti-Adipogenic, Anti-Cancer, and AntiInflammatory Activities InVitro. J. Life Sci. 2013, 5, 127-132. [CrossRef]

45. Harris, J.C.; Cottrell, S.L.; Plummer, S.; Lloyd, D. Antimicrobial properties of Allium sativum (garlic). Appl. Microbiol. Biotechol. 2001, 57, 282-286. [CrossRef] [PubMed]

46. Thamburan, S.; Klaasen, J.; Mabusela, W.T.; Cannon, J.F.; Folk, W.; Johnson, Q. Tulbaghia alliacea phytotherapy: A potential anti-infective remedy for candidiasis. Phytother. Res. 2006, 20, 844-850. [CrossRef] [PubMed]

47. Sobenin, I.A.; Myasoedova, V.A.; Iltchuk, M.I.; Zhang, D.W.; Orekhov, A.N. Therapeutic effects of garlic in cardiovascular atherosclerotic disease. Chin. J. Nat. Med. 2019, 17, 721-728. [CrossRef]

48. Braicu, C.; Mehterov, N.; Vladimirov, B.; Sarafian, V.; Nabavi, S.M.; Atanasov, A.G.; Berindan-Neagoe, I. Nutrigenomics in cancer: Revisiting the effects of natural compounds. Sem. Cancer Biol. 2017, 46, 84-106. [CrossRef]

49. Bhaumik, I.; Pal, K.; Debnath, U.; Karmakar, P.; Jana, K.; Misra, A.K. Natural product inspired allicin analogs as novel anti-cancer agents. Bioorg. Chem. 2019, 86, 259-272. [CrossRef]

50. Braicu, C.; Zanoaga, O.; Zimta, A.A.; Tigu, A.B.; Kilpatrick, K.L.; Bishayee, A.; Nabavi, S.M.; Berindan-Neagoe, I. Natural compounds modulate the crosstalk between apoptosis- and autophagy-regulated signaling pathways: Controlling the uncontrolled expansion of tumor cells. Sem. Cancer Biol. 2020. [CrossRef]

51. Budisan, L.; Gulei, D.; Jurj, A.; Braicu, C.; Zanoaga, O.; Cojocneanu, R.; Pop, L.; Raduly, L.; Barbat, A.; Moldovan, A.; et al. Inhibitory Effect of CAPE and Kaempferol in Colon Cancer Cell Lines-Possible Implications in New Therapeutic Strategies. Int. J. Mol. Sci. 2019, 20, 1199. [CrossRef]

52. Alberts, B.; Johnson, A.; Lewis, J.; Raff, M.; Roberts, K.; Walter, P. Molecular Biology of the Cell, 4th ed.; Garland Science: New York, NY, USA, 2002. 
53. Blázquez, S.; Sirvent, J.J.; Olona, M.; Aguilar, C.; Pelegri, A.; Garcia, J.F.; Palacios, J. Caspase-3 and caspase-6 in ductal breast carcinoma: A descriptive study. Histol. Histopathol. 2006, 21, 1321-1329. [CrossRef]

54. Farhadi, F.; Jahanpour, S.; Hazem, K.; Aghbali, A.; Baradran, B.; Vahid Pakdel, S.M. Garlic ((Allium sativum)) Fresh Juice Induces Apoptosis in Human Oral Squamous Cell Carcinoma: The Involvement of Caspase-3, Bax and Bcl-2. J. Dent. Res. Dent. Clin. Dent. Prosp. 2015, 9, 267-273. [CrossRef] [PubMed]

55. Chelikani, P.; Fita, I.; Loewen, P.C. Diversity of structures and properties among catalases. Cell. Mol. Life Sci. 2004, 61, 192-208. [CrossRef] [PubMed]

56. Chan, F.K.; Moriwaki, K.; De Rosa, M.J. Detection of necrosis by release of lactate dehydrogenase activity. Meth. Mol. Biol. (Clifton N. J.) 2013, 979, 65-70. [CrossRef]

57. Borlinghaus, J.; Albrecht, F.; Gruhlke, M.C.; Nwachukwu, I.D.; Slusarenko, A.J. Allicin: Chemistry and biological properties. Molecules 2014, 19, 12591-12618. [CrossRef] [PubMed]

58. Shin, D.Y.; Kim, G.Y.; Hwang, H.J.; Kim, W.J.; Choi, Y.H. Diallyl trisulfide-induced apoptosis of bladder cancer cells is caspasedependent and regulated by PI3K/Akt and JNK pathways. Environ. Toxicol. Pharm. 2014, 37, 74-83. [CrossRef]

59. Gao, X.Y.; Geng, X.J.; Zhai, W.L.; Zhang, X.W.; Wei, Y.; Hou, G.J. Effect of combined treatment with cyclophosphamidum and allicin on neuroblastoma-bearing mice. Asian Pac. J. Trop. Med. 2015, 8, 137-141. [CrossRef]

60. Maldonado, P.D.; Barrera, D.; Medina-Campos, O.N.; Hernández-Pando, R.; Ibarra-Rubio, M.a.E.; Pedraza-Chaverrí, J. Aged garlic extract attenuates gentamicin induced renal damage and oxidative stress in rats. Life Sci. 2003, 73, 2543-2556. [CrossRef]

61. Razo-Rodríguez, A.C.; Chirino, Y.I.; Sánchez-González, D.J.; Martínez-Martínez, C.M.; Cruz, C.; Pedraza-Chaverri, J. Garlic powder ameliorates cisplatin-induced nephrotoxicity and oxidative stress. J. Med. Food 2008, 11, 582-586. [CrossRef]

62. Lee, D.Y.; Li, H.; Lim, H.J.; Lee, H.J.; Jeon, R.; Ryu, J.H. Anti-inflammatory activity of sulfur-containing compounds from garlic. J. Med. Food 2012, 15, 992-999. [CrossRef]

63. Wang, H.C.; Pao, J.; Lin, S.Y.; Sheen, L.Y. Molecular mechanisms of garlic-derived allyl sulfides in the inhibition of skin cancer progression. Ann. N. Y. Acad. Sci. 2012, 1271, 44-52. [CrossRef]

64. Lu, X.; Rasco, B.A.; Jabal, J.M.; Aston, D.E.; Lin, M.; Konkel, M.E. Investigating antibacterial effects of garlic (Allium sativum) concentrate and garlic-derived organosulfur compounds on Campylobacter jejuni by using Fourier transform infrared spectroscopy, Raman spectroscopy, and electron microscopy. Appl. Environ. Microbiol. 2011, 77, 5257-5269. [CrossRef] [PubMed]

65. Hirayama, Y.; Takanari, J.; Goto, K.; Ueda, H.; Tanaka, A.; Nishihira, J. Effect of Welsh onion (Allium fistulosum L.) green leaf extract on immune response in healthy subjects: A randomized, double-blind, placebo-controlled study. Funct. Foods Health Dis. 2019, 9. [CrossRef]

66. Song, B.; Shu, Y.; Cui, T.; Fu, P. Allicin inhibits human renal clear cell carcinoma progression via suppressing HIF pathway. Int. J. Clin. Exp. Med. 2015, 8, 20573-20580. [PubMed]

67. Xiang, Y.; Zhao, J.; Zhao, M.; Wang, K. Allicin activates autophagic cell death to alleviate the malignant development of thyroid cancer. Exp. Med. 2018, 15, 3537-3543. [CrossRef]

68. Zhang, Q.; Yang, D. Allicin suppresses the migration and invasion in cervical cancer cells mainly by inhibiting NRF2. Exp. Ther. Med. 2019, 17, 1523-1528. [CrossRef]

69. Zou, X.; Liang, J.; Sun, J.; Hu, X.; Lei, L.; Wu, D.; Liu, L. Allicin sensitizes hepatocellular cancer cells to anti-tumor activity of 5-fluorouracil through ROS-mediated mitochondrial pathway. J. Pharm. Sci. 2016, 131, 233-240. [CrossRef]

70. Li, C.; Jing, H.; Ma, G.; Liang, P. Allicin induces apoptosis through activation of both intrinsic and extrinsic pathways in glioma cells. Mol. Med. Rep. 2018, 17, 5976-5981. [CrossRef]

71. Fujimoto, A.; Sakanashi, Y.; Matsui, H.; Oyama, T.; Nishimura, Y.; Masuda, T.; Oyama, Y. Cytometric analysis of cytotoxicity of polyphenols and related phenolics to rat thymocytes: Potent cytotoxicity of resveratrol to normal cells. Basic Clin. Pharm. Toxicol. 2009, 104, 455-462. [CrossRef]

72. Mot, A.C.; Damian, G.; Sarbu, C.; Silaghi-Dumitrescu, R. Redox reactivity in propolis: Direct detection of free radicals in basic medium and interaction with hemoglobin. Redox. Rep. 2009, 14, 267-274. [CrossRef]

73. Miron, T.; Shin, I.; Feigenblat, G.; Weiner, L.; Mirelman, D.; Wilchek, M.; Rabinkov, A. A spectrophotometric assay for allicin, alliin, and alliinase (alliin lyase) with a chromogenic thiol: Reaction of 4-mercaptopyridine with thiosulfinates. Anal. Biochem. 2002, 307, 76-83. [CrossRef]

74. Perde-Schrepler, M.; Chereches, G.; Brie, L.; Virag, P.; Barbos, O.; Soritau, O.; Tatomir, C.; Fischer-Fodor, E.; Filip, A.; Vlase, L.; et al. Photoprotective effect of Calluna vulgaris extract against UVB-induced phototoxicity in human immortalized keratinocytes. J. Environ. Pathol. Toxicol. Oncol. 2011, 30, 323-331. [CrossRef] [PubMed]

75. Perde-Schrepler, M.; David, L.; Olenic, L.; Potara, M.; Fischer-Fodor, E.; Virag, P.; Imre-Lucaci, F.; Brie, I.; Florea, A. Gold Nanoparticles Synthesized with a Polyphenols-Rich Extract from Cornelian Cherry (Cornus mas) Fruits: Effects on Human Skin Cells. J. Nanomat. 2016, 2016, 6986370. [CrossRef]

76. Vives-Bauza, C.; Starkov, A.; Garcia-Arumi, E. Measurements of the antioxidant enzyme activities of superoxide dismutase, catalase, and glutathione peroxidase. Meth. Cell Biol. 2007, 80, 379-393. [CrossRef] 